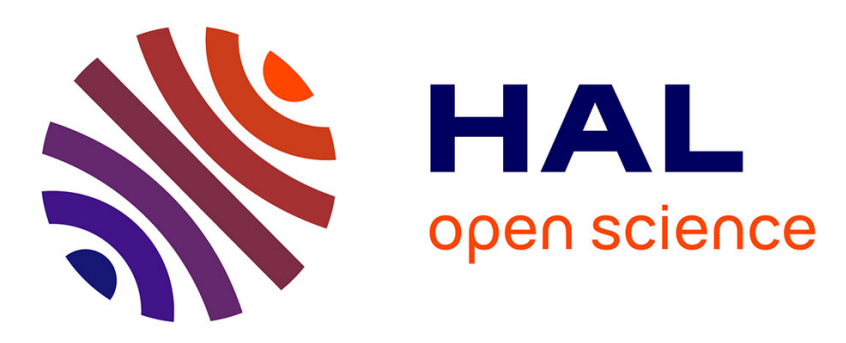

\title{
Coordination properties of two new Schiff-base phenoxy-carboxylates and comparative study of their antioxidant activities
}

\author{
Ahlem Boussadia, Adel Beghidja, Lynda Gali, Chahrazed Beghidja, Mourad \\ Elhabiri, Pierre Rabu, Guillaume Rogez
}

\section{To cite this version:}

Ahlem Boussadia, Adel Beghidja, Lynda Gali, Chahrazed Beghidja, Mourad Elhabiri, et al.. Coordination properties of two new Schiff-base phenoxy-carboxylates and comparative study of their antioxidant activities. Inorganica Chimica Acta, 2020, 508, pp.119656. 10.1016/j.ica.2020.119656 . hal-02614502

\author{
HAL Id: hal-02614502 \\ https://hal.science/hal-02614502
}

Submitted on 9 Nov 2020

HAL is a multi-disciplinary open access archive for the deposit and dissemination of scientific research documents, whether they are published or not. The documents may come from teaching and research institutions in France or abroad, or from public or private research centers.
L'archive ouverte pluridisciplinaire HAL, est destinée au dépôt et à la diffusion de documents scientifiques de niveau recherche, publiés ou non, émanant des établissements d'enseignement et de recherche français ou étrangers, des laboratoires publics ou privés. 


\title{
Coordination properties of two new Schiff-base phenoxy- carboxylates and comparative study of their antioxidant activities.
}

\author{
Ahlem Boussadia, ${ }^{[a]}$ Adel Beghidja, ${ }^{[a]}$ Lynda Gali, ${ }^{[b]}$ Chahrazed Beghidja, ${ }^{[a]}$ \\ Mourad Elhabiri, ${ }^{[\mathrm{c}]}$ Pierre Rabu $^{[\mathrm{d}]}$ and Guillaume Rogez ${ }^{[\mathrm{d}]}$
}

a. Unité de Recherche de Chimie de l'Environnement et Moléculaire Structurale (CHEMS), Université Frères Mentouri Constantine, Route Aïn elbey, 25000 Constantine, Algeria. E-mail : beghidja@umc.edu.dz

b. Centre de Recherche en Biotechnologie, Ali Mendjeli Nouvelle Ville UV 03, 25000 Constantine, Algeria.

c. Équipe Chimie Bioorganique et Médicinale, LIMA, UMR 7042 CNRS, ECPM, Université de Strasbourg, Université de Haute-Alsace, 25 Rue Becquerel, 67000 Strasbourg, France.

d. Institut de Physique et Chimie des Matériaux de Strasbourg (IPCMS), UMR7504 CNRS, Université de Strasbourg, 23 Rue du Loess, F-67034 Strasbourg, France.

\section{Abstract:}

Two novel tridentate Schiff-base ligands containing carboxylate groups were obtained from the condensation of 3-amino-4-hydroxybenzoic acid with either acetylacetone $\left(\boldsymbol{H}_{3} \boldsymbol{L}^{\boldsymbol{l}}\right)$ or salicylaldehyde $\left(\boldsymbol{H}_{3} \boldsymbol{L}^{2}\right) . \quad \boldsymbol{H}_{3} \boldsymbol{L}^{\boldsymbol{1}}$ reacted with copper(II) acetate and pyridine (strongly coordinating solvent) to afford the $\boldsymbol{C l}$ complex, while reaction of $\boldsymbol{H}_{3} \boldsymbol{L}^{2}$ with nickel(II) acetate and pyridine afforded two types of complexes $\boldsymbol{C} 2$ and $\boldsymbol{C} 3$. The two ligands and their metal complexes were fully characterized by elemental analysis, XRD and spectroscopic analysis. Upon its fully deprotonated state, $\left(\boldsymbol{L}^{\boldsymbol{l}}\right)^{3-}$ coordinates in a keto-enamine fashion and acts as a ditopic binder through an ONO tridentate donor system and an $\mathrm{O}$ monodentate donor system (carboxylate). Upon its doubly deprotonated state, $\left(\boldsymbol{H} \boldsymbol{L}^{2}\right)^{2-}$ ligand acts either as monotopic tridentate binder (i.e. enol-imine form with an ONO donor system that lead to complex $\boldsymbol{C 2}$ ) or as a ditopic ligand (ONO tridentate and $\mathrm{O}$ monodentate donor systems to afford complex $\boldsymbol{C 3}$ ). The molecular structure of all the compounds were determined by single crystal X-ray diffraction studies and revealed several important characteristics. In complex $\boldsymbol{C 1}$, the $\mathrm{Cu}$ (II) cations are five-coordinated with a slightly distorted square pyramidal geometry, while in $\boldsymbol{C 2}$ and $\boldsymbol{C 3}$ complexes, the $\mathrm{Ni}$ (II) ions are four and six-coordinated with a square planar and a slightly distorted octahedral geometry, respectively. Following this structural investigation, the antioxidant activities of the free ligands and their metal complexes were then investigated and demonstrated interesting antioxidant features especially for $\boldsymbol{H}_{3} \boldsymbol{L}^{2}$ and complex $\boldsymbol{C} 3$. Lastly, temperature dependent magnetic susceptibility measurements showed the presence of ferromagnetic interactions in $\boldsymbol{C l}$ mediated through the phenoxido bridges.

Keywords: Schiff-base carboxylate / Hydroxy-aminobenzoic acid / Antioxidant activities / Phenoxido-bridges / X-ray crystal structures / Magnetic properties. 


\section{Introduction}

Schiff-based derivatives have received considerable attention due to their ease of production and their multiple uses. ${ }^{[1]}$ The versatility of applications primarily derives from the presence of carbon-nitrogen double bond. ${ }^{[2]}$ Schiff bases have found applications in many areas such as analytical, biological, ${ }^{[2-4]}$ or inorganic chemistry. ${ }^{[5]}$ They have been widely used in the field of coordination chemistry, particularly because of intramolecular hydrogen bonds between atoms $(\mathrm{O})$ and $(\mathrm{N})$, which play a predominant role in the formation of metal complexes. Schiff-based compounds have also shown photochromic and thermochromic properties in the solid state by proton-transfer from the hydroxyl $(\mathrm{O})$ to the imine $(\mathrm{N})$ atoms. ${ }^{[6]}$ Finally, these compounds have also been shown to be important intermediates in many enzymatic reactions involving interaction of the enzyme with the amino or carbonyl group of the substrate. ${ }^{[7]}$

The chemistry of Schiff bases transition metals complexes has been the subject of several investigations and has been developed gradually over the past decades, mostly due to their multifunctional properties based on luminescence, ${ }^{[8,}$ 9] biological functions, ${ }^{[10-13]}$ magnetism, ${ }^{[14-18]}$ catalysis ${ }^{[19,20]}$ or redox chemistry. ${ }^{[21,22]}$ In this sense, many complexes have been reported so far. Among all the transition metal complexes, excellent models for the study of keto-enol tautomerism both in solution and in solid state have been described. ${ }^{[23]}$ On the other hand, Schiff-base ligands with carboxylate functions and various coordination modes favourable to the achievement of multidimensional architectures are of particular interest for the construction of new simple chiral coordination compounds. ${ }^{[17]}$ It is indeed well-known that a carboxylate group can bridge two metal ions to lead to a wide variety of polynuclear complexes ranging from discrete entities to three-dimensional systems. ${ }^{[24,25]}$ Within these complexes, a carboxylate group can thus assume many types of bridging conformations, the most important being triatomic syn-syn, anti-anti, and syn-anti and monatomic. ${ }^{[17,26-30]}$

On the other hand, phenoxo-bridged complexes are an important family of compounds in the field of molecular magnetism. The magnetic properties of phenoxo-bridged complexes containing the $\mathrm{Cu}_{2} \mathrm{O}_{2}$ pattern depend on the structural properties of this core. Factors such as the coordination geometry of the copper cations, the $\mathrm{Cu}-\mathrm{O}-\mathrm{Cu}$ angle, the $\mathrm{Cu}-\mathrm{O}$ bond lengths, the $\mathrm{Cu} \cdots \mathrm{Cu}$ distances, Addison parameter and torsion angle are among the parameters that have been postulated to influence the $J$ values of the spin coupling. ${ }^{[16,31]}$

Herein, we report the synthesis of two Schiff-base compounds containing a carboxylate group (scheme 1) and their corresponding metal complexes $(\mathrm{Ni}, \mathrm{Cu})$. These 
ligands have been mainly designed to lead to functional multidimensional metal-based structural architectures by using the bridging capacities of the carboxylates. These metal complexes have been fully characterized spectroscopically and crystallographically and assessed for their magnetic properties. In addition, the reported positive effects of Schiff bases and their metal complexes on clinically relevant pathogens have recently attracted increasing interest. For example, it has been proposed to use them to develop agrochemicals or drugs, including fungicides, bactericides, antivirals, antioxidants, antiproliferative or antimicrobial drugs. ${ }^{[32]}$ With respect to their antioxidant properties, the attachment of hydroxyl groups to the aromatic ring usually makes the corresponding Schiff bases more effectively antioxidant, thus opening up opportunities for the design of potential drugs to prevent diseases related to free radical damage. We have therefore examined in this study the antioxidant properties of the ligands and complexes we synthesized and discuss their possible mechanism of action. ${ }^{[33]}$
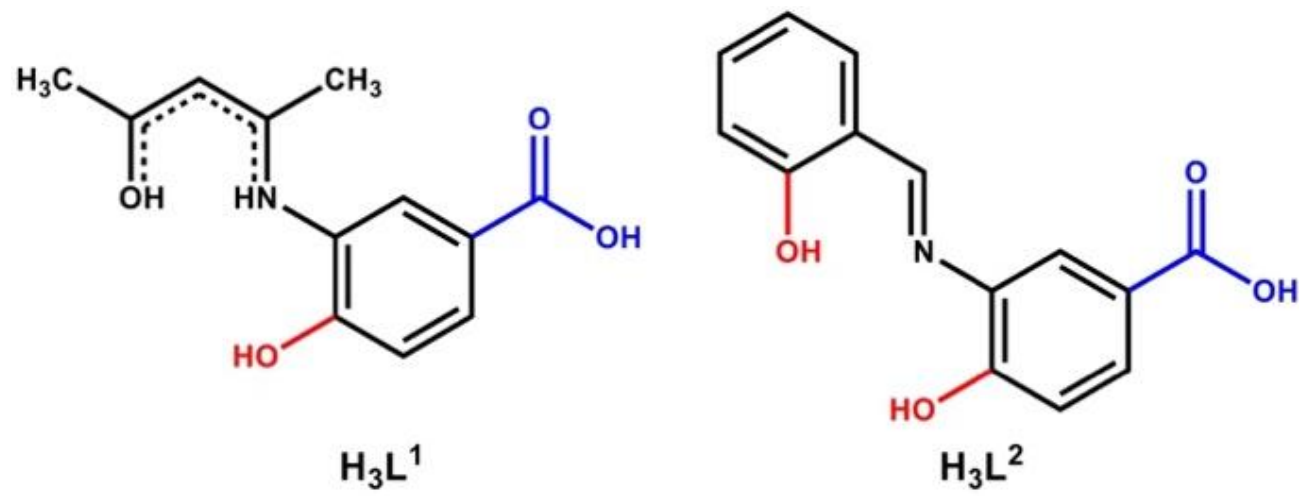

Scheme 1: Molecular structures of the tetradentate ligands

\section{Experimental}

\subsection{Materials and Methods.}

All synthetic procedures were performed under aerobic conditions, and all of the reagents and chemicals were obtained through commercial sources and used without further purification. 3amino-4-hydroxybenzoic acid, acetylacetone, copper and nickel acetate salts were purchased from Alfa Aesar. Elemental analyses $(\mathrm{C}, \mathrm{H}, \mathrm{N})$ was carried out with a Thermo Fisher Scientific Flash 2000. FT-IR spectra were recorded on a Perkin-Elmer Spectrum two on ATR mode in the region $400-4000 \mathrm{~cm}^{-1}$ (Figure S1-S2). The electronic spectra were recorded on a UV/Vis. absorption spectrophotometer Shimadzu 1601-PC with $1 \mathrm{~cm}$ optical quartz cells. ${ }^{1} \mathrm{H}$ NMR spectra were recorded at $300 \mathrm{MHz}$ and ${ }^{13} \mathrm{C}$ NMR spectra at $75 \mathrm{MHz}$ on a Bruker AVANCE 300 instrument. Resonance patterns are reported with the following notations: br 
(broad), s (singlet), d (doublet), t (triplet), q (quartet), m (multiplet), dd (doublet of doublets) (Figure S3-S4). Data for antioxidant activities are given as means \pm standard deviation (SD) of three independent measurements. Magnetic studies were carried out using a SQUID magnetometer (Quantum Design MPMS-3) covering the temperature and field ranges 1.8 $300 \mathrm{~K}, \pm 70 \mathrm{kOe}$. Susceptibility was measured on heating in an applied field of $5 \mathrm{kOe}$. The data were corrected for the sample holder and the diamagnetic contributions calculated from Pascal's constants. Magnetization measurements at different fields at room temperature confirm the absence of magnetic impurities.

\subsection{Single-Crystal X-ray Diffraction Studies}

Diffraction intensities for all compounds were collected on a Bruker-AXS APEX II CCD diffractometer at 296(2) K. The crystallographic data, conditions retained for the intensity data collection and some features of the structure refinements are listed in Table 1. The intensities were collected with Mo K $\alpha$ radiation $(\lambda=0.71073 \AA)$. Data processing, Lorentzpolarization were performed using APEX2. ${ }^{[34]}$ The structure was solved by direct methods and refined by full-matrix least-squares methods on $\mathrm{F}^{2}$, using the SHELXL-2018 program package. ${ }^{[35]}$ All non-hydrogen atoms were refined anisotropically. The hydrogen atoms were located from difference Fourier maps, assigned with isotropic displacement factors and included in the final refinement cycles by use of geometrical constraints. Molecular plots were performed with the CrystalMaker and MERCURY programs. ${ }^{[36,37]}$ Selected bond lengths and angles are summarized in Table S1. Table S2 lists of the hydrogen bond interactions in compounds $1-5$. Geometrical calculations were carried out with PLATON. ${ }^{[38]}$ CCDC 1949764-1949768 contains the supplementary crystallographic data for this contribution. These data can be obtained free of charge via www.ccdc.cam.ac.uk/conts/retrieving.html (or from the Cambridge Crystallographic Data Centre, 12 Union Road, Cambridge CB2 1EZ, UK; fax: (+44) 1223-336-033; or deposit@ccdc.ca.ac.uk). 
Table 1: Crystal data and experimental parameters of structures 1 - 5

\begin{tabular}{|c|c|c|c|c|c|}
\hline Compounds reference & $\mathrm{H}_{3} \mathrm{~L}^{\mathrm{I}}$ & $\mathrm{H}_{3} L^{2}$ & $C 1$ & $C 2$ & C3 \\
\hline Chemical formula & $\mathrm{C}_{12} \mathrm{H}_{13} \mathrm{NO}_{4}$ & $\mathrm{C}_{28} \mathrm{H}_{22} \mathrm{~N}_{2} \mathrm{O}_{8}$ & $\mathrm{C}_{49} \mathrm{H}_{45} \mathrm{Cu}_{3} \mathrm{~N}_{7} \mathrm{O}_{8}$ & $\mathrm{C}_{19} \mathrm{H}_{14} \mathrm{~N}_{2} \mathrm{NiO}_{4}$ & $\mathrm{C}_{25} \mathrm{H}_{22} \mathrm{~N}_{3} \mathrm{NiO}_{5}$ \\
\hline Formula weight $\mathrm{MW}\left(\mathrm{g} \mathrm{mol}^{-1}\right)$ & 235.23 & 514.47 & 1050.54 & 393.03 & 504.17 \\
\hline Crystal system & Monoclinic & Monoclinic & Monoclinic & Monoclinic & Orthorhombic \\
\hline Space group & $P 2_{1} / c$ & $P 2_{1} / n$ & $P 2 / c$ & $P 2_{1} / n$ & Pbca \\
\hline Temperature $(\mathrm{K})$ & $296(1)$ & $296(1)$ & $296(1)$ & $296(1)$ & $296(1)$ \\
\hline $\mathrm{a}(\AA)$ & $4.8639(3)$ & $12.0325(4)$ & $18.7592(7)$ & $4.8085(3)$ & $17.0836(5)$ \\
\hline $\mathrm{b}(\AA)$ & $16.5889(12)$ & $10.4098(4)$ & $9.7333(4)$ & $10.1516(6)$ & $15.8683(5)$ \\
\hline$c(\AA)$ & $13.7485(8)$ & $19.4563(7)$ & $16.0077(6)$ & $33.3476(19)$ & $17.8681(4)$ \\
\hline$\beta\left(^{\circ}\right)$ & $97.091(3)$ & $103.904(2)$ & $106.724(2)$ & $91.218(3)$ & 90 \\
\hline $\mathrm{V}\left(\AA^{3}\right)$ & $1100.84(12)$ & $2365.61(15)$ & $2799.20(19)$ & $1627.46(17)$ & $4843.8(2)$ \\
\hline $\mathrm{Z}$ & 4 & 4 & 4 & 4 & 8 \\
\hline$\rho$ calc. $\left(\right.$ g.cm $\left.{ }^{-1}\right)$ & 1.419 & 1.444 & 1.246 & 1.604 & 1.383 \\
\hline$\mu\left(\mathrm{mm}^{-1}\right)$ & 0.107 & 0.107 & 1.181 & 1.221 & 0.841 \\
\hline Wavelength $\lambda, \AA$ & 0.71073 & 0.71073 & 0.71073 & 0.71073 & 0.71073 \\
\hline Independent reflections & $\begin{aligned} 2753\left[R_{\text {int }}\right. & =0.0274 \\
R_{\text {sigma }} & = \\
0.0285] & \end{aligned}$ & $\begin{aligned} 4761\left[R_{\text {int }}\right. & =0.0704, \\
R_{\text {sigma }} & = \\
0.0791] & \end{aligned}$ & $\begin{aligned} 4854\left[\mathrm{R}_{\mathrm{int}}\right. & =0.0520, \\
\mathrm{R}_{\text {sigma }} & =0.0557]\end{aligned}$ & $\begin{aligned} 3954\left[\mathrm{R}_{\text {int }}\right. & =0.0817 \\
\mathrm{R}_{\text {sigma }} & =0.0965]\end{aligned}$ & $\begin{aligned} 4810\left[\mathrm{R}_{\mathrm{int}}\right. & =0.0533, \\
\mathrm{R}_{\mathrm{sigma}} & =0.0911]\end{aligned}$ \\
\hline Data/restraints/parameters & $2753 / 0 / 158$ & $4791 / 0 / 347$ & $4866 / 0 / 306$ & $3954 / 0 / 249$ & $4810 / 0 / 310$ \\
\hline $\begin{array}{l}\mathrm{R}\left[\mathrm{F}^{2}>2 \sigma\left(\mathrm{F}^{2}\right)\right]^{\mathrm{a}} ; \mathrm{R}\left[\mathrm{F}^{2} \text { (all }\right. \\
\text { data) }]^{\mathrm{a}} \\
\mathrm{wR}\left[\mathrm{F}^{2}>2 \sigma\left(\mathrm{F}^{2}\right)\right]^{\mathrm{b}} ; \mathrm{wR}\left[\mathrm{F}^{2} \text { (all }\right. \\
\text { data) }]^{\mathrm{b}} \\
\text { Goodness-of-fit }\left(\mathrm{F}^{2}\right)\end{array}$ & $\begin{array}{l}0.0445 ; 0.0685 \\
0.01097 ; 0.1227 \\
1.038\end{array}$ & $\begin{array}{l}0.0509 ; 0.1245 \\
0.1152 ; 0.1439 \\
0.984\end{array}$ & $\begin{array}{l}0.0784 ; 0.1037 \\
0.2251 ; 0.2500 \\
1.038\end{array}$ & $\begin{array}{l}0.0508 ; 0.1174 \\
0.0911 ; 0.0911 \\
0.987\end{array}$ & $\begin{array}{l}0.0525 ; 0.1210 \\
0.1032 ; 0.1266 \\
1.001\end{array}$ \\
\hline Largest diff. peak/hole, e $\AA^{-3}$ & $0.24 /-0.20$ & $0.19 /-0.21$ & $1.75 /-0.47$ & $0.30 /-0.31$ & $0.42 /-0.28$ \\
\hline
\end{tabular}

${ }^{\mathrm{a}} \mathrm{R} 1=\Sigma|| \mathrm{F}_{\mathrm{O}}|-| \mathrm{F}_{\mathrm{c}} \| / \Sigma\left|\mathrm{F}_{\mathrm{O}}\right|{ }^{\mathrm{b}}{ }_{\mathrm{wR} 2}=\left[\Sigma \mathrm{w}\left(\mathrm{F}_{\mathrm{O}}{ }^{2}-\mathrm{F}_{\mathrm{c}}{ }^{2}\right)^{2}\right] /\left[\Sigma \mathrm{w}\left(\mathrm{F}_{\mathrm{O}}{ }^{2}\right)^{2}\right]^{1 / 2} \cdot{ }^{\mathrm{c}}$ Goodness-of-fit $\mathrm{S}=\left[\Sigma \mathrm{w}\left(\mathrm{F}_{\mathrm{O}}{ }^{2}-\mathrm{F}_{\mathrm{c}}{ }^{2}\right)^{2} /(\mathrm{n}-\mathrm{p})\right]^{1 / 2}$, where $\mathrm{n}$ is the number of reflections and $\mathrm{p}$ the number of parameters. 


\subsection{Preparation of ligands and complexes}

\subsubsection{Synthesis of the ligand $1\left(H_{3} L^{l}\right)$}

The ligand $\boldsymbol{H}_{3} \boldsymbol{L}^{1}$ was synthesized by adding dropwise acetylacetone $(0.654 \mathrm{~g}, 6.53 \mathrm{mmol})$ dissolved in $5 \mathrm{~mL}$ of $\mathrm{MeOH}$ to a stirred methanol solution of 3-amino-4-hydroxybenzoic acid ( $1 \mathrm{~g}, 6.53 \mathrm{mmol}, 10 \mathrm{~mL}$ of $\mathrm{MeOH})$. The resulting mixture was refluxed for 24 hours at $70^{\circ} \mathrm{C}$ to ensure completion of the reaction. Yellow precipitate was obtained, filtered and dried to afford $\boldsymbol{H}_{3} \boldsymbol{L}^{\boldsymbol{1}}$ (1.353 g, 88.1\%). The resulting precipitate was recrystallized in $\mathrm{MeOH}$ to give yellow crystals by slow evaporation after 2 days. Selected FT-IR data, $v\left(\mathrm{~cm}^{-1}\right): 3177(\mathrm{OH})$, $1674(\mathrm{C}=\mathrm{N}), 1591,1574,1455$ (COO), 1279, 1104, 1023, 765. Spectroscopic NMR data (in DMSO-d ${ }^{6}$,): ${ }^{1} \mathrm{H}$ NMR (300 MHz) $\delta: 12.99$ (s, 1H, OH), 12.19 (s, 1H, NH), $10.86(\mathrm{~s}, 1 \mathrm{H}, \mathrm{OH})$, 7.70 (d, J = 2 Hz, 1H, Ar), 7.64 (dd, J=8.4,2 1H, Ar), 6.99 (d, J = 8.4 Hz, 1H, Ar), 5.25 (s, 1H, $\mathrm{CH}), 2.01$ (s, 3H, CH3), 1.99 (s, 3H, CH3). ${ }^{13} \mathrm{C}\left\{{ }^{1} \mathrm{H}\right\} \mathrm{NMR}(75 \mathrm{MHz}) \delta: 195.24,167.35$, 159.89, 154.83, 128.22, 126.70, 122.08, 115.81, 98.35, 29.42, 22.04. Anal. Calc. For $\mathrm{C}_{12} \mathrm{H}_{13} \mathrm{NO}_{4}(\%): \mathrm{C}: 61.27, \mathrm{H}: 5.57, \mathrm{~N}: 5.95$; found: C: 61.19, H: 5.53, N: 5.94.

\subsubsection{Synthesis of the ligand $2\left(\mathrm{H}_{3} L^{2}\right)$}

Methanol solution of salicylaldehyde $(0.797 \mathrm{~g}, 6.52 \mathrm{mmol}, 5 \mathrm{~mL}$ of $\mathrm{MeOH})$ was added dropwise to a stirred solution of 3-amino-4-hydroxybenzoic acid (1 g, $6.53 \mathrm{mmol})$ dissolved in $10 \mathrm{~mL}$ of $\mathrm{MeOH}$. The mixture was heated at reflux at $70^{\circ} \mathrm{C}$ for 24 hours to ensure completion of the reaction. An orange precipitate was obtained, filtered and dried to afford $\boldsymbol{H}_{3} \boldsymbol{L}^{2}(1.5 \mathrm{~g}, 89.4 \%)$. The resulting precipitate was recrystallized in $\mathrm{MeOH}$ to give orange crystals by slow evaporation after 3 days. Selected FT-IR data, $v\left(\mathrm{~cm}^{-1}\right): 3069(\mathrm{OH}), 1692$ $(\mathrm{C}=\mathrm{N}), 1607,1513,1363$ (COO), 1297, 1198, 1015, 737. Spectroscopic NMR data (in DMSO-d ${ }^{6}$ ): ${ }^{1} \mathrm{H}$ NMR (300 MHz) $\delta: 13.55$ (s, 1H, OH), $12.66(\mathrm{~s}, 1 \mathrm{H}, \mathrm{OH}), 10.58(\mathrm{~s}, 1 \mathrm{H}, \mathrm{OH})$, 9.05 (s, 1H, CH), 7.91 (d, 1H, J= 2.4 Hz, 1H, Ar), 7.75 (dd, J= 8.4, 2 Hz, 1H, Ar), 7.69 (dd, $\mathrm{J}=7.6,1.62$ 1H, Ar), 7.41 (td, J= 7.2, 1.6 Hz, 1H, Ar), 7.04 (d, J = 8.4 Hz, 1H, Ar), 6.98 (dd, J $=7.6,1.2 \mathrm{~Hz}, 1 \mathrm{H}, \mathrm{Ar}), 6.95(\mathrm{td}, \mathrm{J}=8.4,1.2 \mathrm{~Hz}, 1 \mathrm{H}, \mathrm{Ar}) .{ }^{13} \mathrm{C}\left\{{ }^{1} \mathrm{H}\right\} \mathrm{NMR}\{\mathrm{H}\}(75 \mathrm{MHz}) \delta$ : $167.47,163.24,161.10,155.78,135.47,133.60$, 133.04, 130.04, 122.57, 121.26, 119.96, 119.33, 117.12, 116.66. Anal. Calc. for $\mathrm{C}_{28} \mathrm{H}_{22} \mathrm{~N}_{2} \mathrm{O}_{8}$ (\%): C: $65.36, \mathrm{H}: 4.31, \mathrm{~N}: 5.45$; found: C: $65.23, \mathrm{H}: 4.33, \mathrm{~N}: 5.39$.

\subsubsection{Synthesis of $\left[\mathrm{Cu}_{3}^{\mathrm{II}}\left(\mathrm{L}^{1}\right)_{2}(\mathrm{Py})_{5}\right]_{\mathrm{n}}(\mathrm{Cl})$}

A mixture of $\mathrm{Cu}(\mathrm{OAc})_{2} .2 \mathrm{H}_{2} \mathrm{O}(0.1 \mathrm{~g}, 0.5 \mathrm{mmol}), \boldsymbol{H}_{3} \boldsymbol{L}^{1}(0.235 \mathrm{~g}, 1 \mathrm{mmol})$ and pyridine $(0.026$ $\mathrm{g}, 0.1 \mathrm{mmol})$ in $5 \mathrm{~mL}$ of dimethylformamide (DMF) was stirred in methanol (MeOH, $10 \mathrm{~mL})$ for 10 hours resulting in a green solution. Green crystals were collected by filtration after 
slow evaporation of the solution for about 10 days. $(0.12 \mathrm{~g}, 45.7 \%$ yield on the basis of $\left.\mathrm{Cu}(\mathrm{OAc})_{2} \cdot 2 \mathrm{H}_{2} \mathrm{O}\right)$. Selected FT-IR data, $v\left(\mathrm{~cm}^{-1}\right): 2905,2794,2565,1874,1659,1580(\mathrm{C}-\mathrm{N})$, 1507, 1399 (COO), 1220, 1112, 1013, 693. Anal. Calc. For $\mathrm{C}_{49} \mathrm{H}_{43} \mathrm{~N}_{7} \mathrm{O}_{8} \mathrm{Cu}_{3}: \mathrm{C}: 56.13 ; \mathrm{H}$ : 4.13; N: 9.35. Found: C: 55.82; H: 4.08; N: 9.60\%.

\subsubsection{Synthesis of $\left[\mathrm{Ni}^{\mathrm{II}}\left(\mathrm{H} L^{2}\right)(\mathrm{Py})\right](C 2)$}

3-amino-4-hydroxybenzoic acid (0.153 g, $1 \mathrm{mmol})$, salicylaldehyde (0.1 mmol, $0.122 \mathrm{~g})$, $\mathrm{Ni}(\mathrm{OAc})_{2} .4 \mathrm{H}_{2} \mathrm{O}(0.12 \mathrm{~g}, 0.5 \mathrm{mmol})$ and pyridine $(0.026 \mathrm{~g}, 0.1 \mathrm{mmol})$ were reacted in $5 \mathrm{~mL}$ of DMF. The mixture was stirred for 3 hours and lead to a red solution. The resulting solution was then filtered. After 2 days single bright red crystals, suitable for single crystal X-ray diffraction, were formed $\left(0.05 \mathrm{~g}, 25.1 \%\right.$ yield on the basis of $\left.\mathrm{Ni}(\mathrm{OAc})_{2} .4 \mathrm{H}_{2} \mathrm{O}\right)$. Selected FTIR data, $v\left(\mathrm{~cm}^{-1}\right): 3753,2938,2792,2654,2507,1887,1672 \mathrm{C}=\mathrm{N}, 1588,1498,1588,1526$, 1449, 1414, 1330, 1289, 1212, 1157, 1080, 753, 551. Anal. Calc. For $\mathrm{C}_{19} \mathrm{H}_{14} \mathrm{~N}_{2} \mathrm{O}_{4} \mathrm{Ni}(\%): \mathrm{C}$ : 58.06, H: 3.59, N: 7.12; found: C: 57.78, H: 3.66, N: 7.02.

\subsubsection{Synthesis of $\left[\mathrm{Ni}^{\mathrm{II}}\left(\mathrm{H}^{2}\right)(\mathrm{Py})_{2}\right]_{\mathrm{n}} \cdot \mathrm{MeOH}(C 3)$}

A mixture of $\boldsymbol{H}_{3} \boldsymbol{L}^{2}$ (2) $(0.257 \mathrm{~g}, 1 \mathrm{mmol}), \mathrm{Ni}(\mathrm{OAc})_{2} .4 \mathrm{H}_{2} \mathrm{O}(0.12 \mathrm{~g}, 0.5 \mathrm{mmol})$ and pyridine $(0.026 \mathrm{~g}, 0.1 \mathrm{mmol})$ in $10 \mathrm{~mL}$ methanol was stirred for 30 minutes resulting in a pale green solution. The resulting solution was then filtered. Green crystals suitable for single crystal Xray diffraction are formed after slow evaporation of the resulting solution for about 7 days and collected by filtration $\left(0.080 \mathrm{~g}, 31.7 \%\right.$ yield on the basis of $\left.\mathrm{Ni}(\mathrm{OAc})_{2} .4 \mathrm{H}_{2} \mathrm{O}\right)$. Selected FT-IR data, $v\left(\mathrm{~cm}^{-1}\right)$ : 3073, $1668 \mathrm{C}=\mathrm{N}, 1586,1498,1444,1327,1292,1129,1037,694$. Anal. Calc. For $\mathrm{C}_{25} \mathrm{H}_{23} \mathrm{~N}_{3} \mathrm{O}_{5} \mathrm{Ni}(\%): C: 59.55, \mathrm{H}: 4.60, \mathrm{~N}: 8.33$; found: C: 58.78, H: 4.36, N: 8.02.

\subsection{Antioxidant activity}

\subsubsection{Reagents}

1,1-Diphenyl-2-picrylhydrazyl (DPPH $\left.{ }^{*}\right), \quad$ butylated-hydroxyanisole (BHA), Butylatedhydroxytoluene (BHT), ascorbic acid, $\beta$-carotene, linoleic acid, polyoxyethylene sorbitan monopalmitate (Tween-40), neocuproine, 2,2'-azino-bis(3-ethylbenzothiazoline-6-sulfonic acid) diammonium salt (ABTS), trichloroacetic acid (TCA), Potassium ferricyanide, 3-(2Pyridyl)-5,6-di(2-furyl)-1,2,4-triazine-5',5"-disulfonic acid disodium salt (Ferene), ethylene diaminetetraacetic acid (EDTA), dimethyl sulfoxide (DMSO) were obtained from Sigma Chemical Co. (Sigma-Aldrich GmbH, Sternheim, Germany), Iron(III) chloride, Iron(II) chloride, Copper(II) chloride, Potassium persulfate, were obtained from Biochem Chemopharma. All other chemicals and solvents were of analytical grade. 


\subsubsection{Evaluation of the antioxidant activity}

\subsubsection{1- Scavenging activity of the $\mathrm{DPPH}^{\circ}$ radical}

The scavenging activity of the stable 1,1-diphenyl-2-picrylhydrazyl ( $\left.\mathrm{DPPH}^{*}\right)$ free radical was determined by the method described by Blois (1958). ${ }^{[39]} \mathrm{DPPH}^{\bullet}$ is a well-known nitrogenbased radical that traps radicals (purple at $\sim 520 \mathrm{~nm}$ ). It is then used as an indicator of the radical nature of a given reaction. The $\mathrm{DPPH}^{*}$ assay was performed in a 96 wells microplate. Typically, $160 \mu \mathrm{L}$ of a DPPH stock solution $(1 \mathrm{mM})$ prepared in methanol was mixed with $40 \mu \mathrm{L}$ of the compound (free ligand or metal complex) prepared at different concentrations. The absorbance was measured at $517 \mathrm{~nm}$ after 30 minutes of reaction using a microplate reader (Perkin Elmer, Enspire). The percentages of the scavenging activity of $\mathrm{DPPH}^{\bullet}$ by the compound were calculated as follows:

$$
\text { DPPH scavenging effect }(\%)=\frac{A_{\text {Control }}-A_{\text {Sample }}}{A_{\text {Control }}} \times 100
$$

Where $\mathrm{A}_{\text {control }}$ and $\mathrm{A}_{\text {sample }}$ are the absorbances of the control ( $\mathrm{DPPH}^{\circ}$ alone) and of the mixture $\left(\mathrm{DPPH}^{\circ}+\right.$ compound $)$ recorded after $30 \mathrm{~min}$ of reaction, respectively. The $\mathrm{IC}_{50}$ values were determined from the inhibition curves measured for different concentrations of the compound. $\mathrm{IC}_{50}$ is be defined as the concentration of the compound required to achieve $50 \%$ inhibition of the $\mathrm{DPPH}^{\circ}$ radical. In this $\mathrm{DPPH}^{\bullet}$ assay, BHA and $\mathrm{BHT}$ were used as standard compounds.

\subsubsection{2- ABTS $^{\cdot+}$ scavenging activity}

In parallel, the antiradical activity against the $\mathrm{ABTS}^{\circ+}$ radical was determined according to the method described by Re et al. ${ }^{[40]} \mathrm{ABTS}^{\bullet+}$ is a blue cation radical $(\sim 734 \mathrm{~nm})$ commonly used to measure the antioxidant capacities of various compounds (e.g., $\mathrm{ABTS}^{\cdot+}$ reacts with phenols, thiols and vitamin C). The $\mathrm{ABTS}^{\circ+}$ was produced by reacting $2 \mathrm{mM}$ of ABTS in $\mathrm{H}_{2} \mathrm{O}$ with $2.45 \mathrm{mM}$ potassium persulfate $\left(\mathrm{K}_{2} \mathrm{~S}_{2} \mathrm{O}_{8}\right)$. The $\mathrm{ABTS}^{\circ+}$ stock solution could be stored away from light at room temperature for $16 \mathrm{~h}$. The $\mathrm{ABTS}^{\circ+}$ solution was then diluted with distilled water to provide a solution with an absorbance of 0.7 at $734 \mathrm{~nm}$. $160 \mu \mathrm{L}$ of this solution was mixed with $40 \mu \mathrm{l}$ of the compound (free ligand or metal complex) in methanol and the absorbance was recorded at $734 \mathrm{~nm}$ after 10 minutes of reaction. Similarly, to DPPH', the percentages of the scavenging activity of $\mathrm{ABTS}^{\bullet+}$ was calculated following formula (1) and the $\mathrm{IC}_{50}$ values were deduced from the inhibition curves measured for different concentrations of the compound. The results obtained with the compounds investigated in this work were also compared to BHA and BHT used as standards. 


\subsubsection{3- $\beta$-Carotene-linoleic acid bleaching inhibition}

The ability of the compound to inhibit the bleaching of a $\beta$-carotene-linoleic acid emulsion was determined using the method developed by Marco. ${ }^{[41]}$ The $\beta$-carotene-linoleic acid bleaching assay $(\beta C)$ is a common method for evaluating antioxidant activity of a compound by absorption spectroscopy at $470 \mathrm{~nm}$ and works on a system of lipid micelles in an aqueous environment. The linoleic acid- $\beta$-carotene emulsion was prepared by dissolving $2 \mathrm{mg}$ of $\beta$ carotene in $1 \mathrm{~mL}$ of chloroform. The solvent was then removed under vacuum using a rotary evaporator. $20 \mu \mathrm{L}$ of linoleic acid and $200 \mu \mathrm{L}$ of Tween- 40 were added to the residue. $50 \mathrm{~mL}$ of $\mathrm{H}_{2} \mathrm{O}_{2}$ was then added to the mixture. The absorbance at $470 \mathrm{~nm}$ was then adjusted to 0.8 0.9. $160 \mu \mathrm{L}$ of the emulsion were next mixed with $40 \mu \mathrm{L}$ of the compound (free ligand or metal complex) or of the standard compounds (BHA and BHT) at different concentrations in a microplate and the absorbance was directly measured $(\mathrm{t}=0)$ at $470 \mathrm{~nm}$. The microplate was maintained at a temperature of $45^{\circ} \mathrm{C}$ and the absorbance values were recorded every $30 \mathrm{~min}$ over 2 hours. The bleaching percentages $(\mathrm{R})$ of $\beta$-carotene-linoleic acid were calculated as follows:

$$
R=\frac{\ln \frac{A(t=0)}{A(t=120)}}{t}
$$

Where $\mathrm{A}_{\text {control }}$ and $\mathrm{A}_{\text {sample }}$ are the absorbances of the control (DPPH ${ }^{\circ}$ alone) and of the mixture $\left(\mathrm{DPPH}^{\bullet}+\right.$ compound $)$ recorded after $30 \mathrm{~min}$ of reaction, respectively. The $\mathrm{IC}_{50}$ values were determined from the inhibition curves measured for different concentrations of the compound. $\mathrm{IC}_{50}$ is be defined as the concentration of the compound required to achieve $50 \%$ inhibition of the $\mathrm{DPPH}^{\circ}$ radical. In this $\mathrm{DPPH}^{\circ}$ assay, BHA and BHT were used as standard compounds.

\subsubsection{4- Reducing power (ferricyanide to ferrocyanide)}

The reducing power was measured by the direct reduction of $\mathrm{Fe}^{3+}\left(\mathrm{CN}^{-}\right)_{6}$ to $\mathrm{Fe}^{2+}\left(\mathrm{CN}^{-}\right)_{6}$, and was determined by measuring absorbance resulted from the formation of the Perl's Prussian Blue complex following the addition ferric ions $\left(\mathrm{Fe}^{3+}\right)$ using the method developed by Oyaizu ${ }^{[42]}$ with some modifications. $10 \mu \mathrm{L}$ of free ligands, metal complexes or standards (BHA, BHT and ascorbic acid) prepared in methanol at different concentrations were mixed with $40 \mu \mathrm{L}$ of sodium phosphate buffer $(0.2 \mathrm{M}, \mathrm{pH} 6.6)$ and $50 \mu \mathrm{L}$ of potassium ferricyanide $\left[\mathrm{K}_{3} \mathrm{Fe}(\mathrm{CN})_{6}\right]$ (1\%). The mixture was incubated at $50{ }^{\circ} \mathrm{C}$ for 20 minutes. After incubation, the reaction mixture was acidified with $50 \mu \mathrm{L}$ of trichloroacetic acid (10\%). Then, $40 \mu \mathrm{L}$ of distilled water and $10 \mu \mathrm{L}$ of $\mathrm{FeCl}_{3}(0.1 \%)$ were added to the mixture, and the absorbance was read at 700 $\mathrm{nm}$. high absorbance values for the reaction mixture thus point out high reduction capabilities. 
The concentration required to achieve an absorbance of $0.5\left(\mathrm{~A}_{0.5}\right)$ was used for comparison purposes and was determined from the absorbances value curves measured at different concentrations of the test compound.

\subsubsection{5- Cupric reducing antioxidant power (CUPRAC)}

The CUPRAC (CUPric Reducing Antioxidant Capacity) method [43, 44] is based on the absorbance measurements of $\mathrm{Cu}(\mathrm{I})$-neocuproine complex formed as a result of an electrontransfer between antioxidants and the CUPRAC reagent (i.e., $\mathrm{Cu}$ (II)-neocuproine complex). The formation of the cuprous-neocuproine complex is assessed at $450 \mathrm{~nm}$ that corresponds to the maximum of absorption of the MLCT transitions. Typically, $50 \mu \mathrm{L}$ of $\mathrm{CuCl}_{2}\left(10^{-2} \mathrm{M}\right), 50$ $\mu \mathrm{L}$ of neocuproine $\left(7.5 .10^{-3} \mathrm{M}\right)$ and $60 \mu \mathrm{L}$ of $\mathrm{CH}_{3} \mathrm{COONH}_{4}(1 \mathrm{M})$ were mixed in $50 \mu \mathrm{L}$ of ethanol and dispersed in a microplate of 96 wells. $40 \mu \mathrm{L}$ of the sample at different concentrations were then added and the absorbances were measured at $450 \mathrm{~nm}$ after 1 hour of incubation. Again, BHA and BHT were used as standards.

\subsubsection{6- Ferrous chelating activity}

The ferrous ion chelating assay (with slight modifications) ${ }^{[45]}$ was finally performed to evaluate the ability of the investigated ligands or complexes in chelating ferrous ion. Ferene can quantitatively form complexes with ferrous iron yielding a blue colour. However, in the presence of competing Fe(II) chelators, formation of this complex can be prevented and thus lead to a subsequent decrease in the Fe(II)-ferene absorption. Measurement of the absorbance of the $\mathrm{Fe}(\mathrm{II})$-ferene thus gives an estimation of the binding capacity of the competing chelator. Typically, to $40 \mu \mathrm{L}$ of each sample (dissolved in methanol), were added $40 \mu \mathrm{L}$ of methanol and $40 \mu \mathrm{L} 0.2 \mathrm{mM} \mathrm{FeCl}_{2}$. The reaction was initiated by adding $80 \mu \mathrm{L}$ of ferene $(0.5$ $\mathrm{mM})$. The mixture was shaken vigorously and left at room temperature for $10 \mathrm{~min}$. The absorbance was then measured at $593 \mathrm{~nm}$. The percentages of the competing activity of the ligands/complexes towards Fe(II)-ferene were calculated using the previously described equation (1) by varying their concentrations. The $\mathrm{IC}_{50}$ values were deduced from the inhibition curves measured for different concentrations of the compounds. Ethylenediaminetetraacetic acid (EDTA) was used as a standard.

\subsubsection{Statistical analysis}

Data for the antioxidant activities are presented as means \pm standard deviation (SD) of three independent measurements. Statistical analysis was performed using a one-way analysis of variance (ANOVA) in the software Origin Pro 9.0. Differences were considered significant at $\mathrm{p}<0.05$. 


\section{Results and Discussion}

\subsection{Synthesis and characterisation}

The ligands $\boldsymbol{H}_{3} \boldsymbol{L}^{1}$ and $\boldsymbol{H}_{3} \boldsymbol{L}^{2}$ were synthesized by simple condensation reaction in methanol $\left(70{ }^{\circ} \mathrm{C}, 24 \mathrm{~h}\right.$ ) between 3-amino-4-hydroxybenzoic acid with acetylacetone or salicylaldehyde, respectively, and were characterized by routine spectroscopic techniques (FT-IR, ${ }^{1} \mathrm{H}$ and ${ }^{13} \mathrm{C}$ NMR, $\mu$-analysis). Complex $\boldsymbol{C l}$ was prepared by reaction of $\mathrm{Cu}(\mathrm{OAc})_{2} .2 \mathrm{H}_{2} \mathrm{O}$ with $\boldsymbol{H}_{3} \boldsymbol{L}^{\boldsymbol{1}}(1: 2$ molar ratio) in pyridine-methanol-DMF solvents mixture $(0.1: 1: 1)$. The reaction of $\mathrm{Ni}(\mathrm{OAc})_{2} \cdot 4 \mathrm{H}_{2} \mathrm{O}$ with $\boldsymbol{H}_{3} \boldsymbol{L}^{2}$ (1:2 molar ratio) in DMF-pyridine solution gave the monomeric complex $\boldsymbol{C 2}$, while the same reaction performed in methanol- pyridine solution led to the polymeric complex $\boldsymbol{C 3}$. The composition and structure of the metal complexes were assessed by routine characterization techniques as well as by single crystal X-ray analysis. The UV-vis. absorption spectra of the ligands and the corresponding complexes $(\boldsymbol{C 1}, \boldsymbol{C 3})$ were recorded in EtOH (Figure 7).

\subsection{Crystal structure descriptions}

\subsubsection{Crystal and molecular structure of the ligand $\boldsymbol{H}_{3} \boldsymbol{L}^{1}$}

Molecular structure of $\boldsymbol{H}_{3} \boldsymbol{L}^{1}$ and the unit cell packing is shown in Figure 1. $\boldsymbol{H}_{3} \boldsymbol{L}^{1}$ coexists in keto-amine and enol-imine tautomeric forms (Figure 3a) and crystallizes in a centrosymmetric space group $P 2{ }_{1} / c$ with four molecules in the cell as a keto-amine tautomer. The molecule is planar and the distance values in the fragment: $\mathrm{N} 1\left(\mathrm{sp}^{3}\right)-\mathrm{C} 8\left(\mathrm{sp}^{2}\right)=\mathrm{C} 10\left(\mathrm{sp}^{2}\right)-\mathrm{C} 11\left(\mathrm{sp}^{2}\right)=\mathrm{O} 4\left(\mathrm{sp}^{2}\right)$ are equal to : $1.38 \AA, 1.39 \AA, 1.42 \AA$ and $1.25 \AA$, respectively. ${ }^{[46]}$ This feature reveals that the $\mathrm{N}-\mathrm{C}-\mathrm{C}-\mathrm{C}-\mathrm{O}$ fragment within these molecules has partial single and double bond character. Besides, the $\mathrm{N}-\mathrm{C}-\mathrm{C}-\mathrm{C}-\mathrm{O}$ fragment is connected via $\mathrm{N}-\mathrm{H} \cdots \mathrm{O}$ intramolecular hydrogen bond forming a delocalized six-membered ring $\mathrm{S}(6)\left(\mathrm{d}_{\mathrm{N} 1-\mathrm{O} 4}=2.65 \AA ; \angle \mathrm{N} 1-\mathrm{H} 1 \mathrm{a}-\mathrm{O} 4=142^{\circ}\right)$. In the crystal packing, the molecules are linked by intermolecular $\mathrm{O}-\mathrm{H} \cdots \mathrm{O}$ hydrogen bonds between carboxylate oxygens $\mathrm{O} 1$ and $\mathrm{O} 2$ and the hydrogen atom of the adjacent carboxylate group : $\left(\mathrm{d}_{\mathrm{O} 1-\mathrm{O} 2 \mathrm{i}}=2.62 \AA ; \angle \mathrm{O} 1-\mathrm{H} 1 \cdots \mathrm{O} 2^{\mathrm{i}}=175^{\circ}\right.$, smmetry $\left.(\mathrm{i})-x+2,-y+2,-z\right)$, and between phenol oxygen $\mathrm{O} 3$ and oxygen $\mathrm{O} 4^{\mathrm{ii}}$ of the carbonyl group of the adjacent molecule $\left(\mathrm{d}_{\mathrm{O} 3-\mathrm{O} 4}{ }^{\mathrm{ii}}=2.69 \AA ; \angle \mathrm{O} 3-\mathrm{H} 3 \cdots \mathrm{O} 4^{\mathrm{ii}}=166^{\circ}\right.$, symmetry (ii) $\left.-x,-y+2,-z+1\right)$, and form an infinite chains along the c-axis (figure 1). The adjacent chains are linked by weak $\mathrm{C}-\mathrm{H} \cdots \mathrm{O}$, intermolecular interactions between the carbon of the methyl group C9 and the oxygen atom of the carboxylate group of the adjacent molecule $\mathrm{O} 2\left(\mathrm{~d}_{\mathrm{C} 9-\mathrm{O} 2}{ }^{\mathrm{iii}}=3.45 \AA ; \angle \mathrm{C} 9-\mathrm{H} 9 \mathrm{~A} \cdots \mathrm{O} 2^{\mathrm{iii}}=\right.$ 
$153^{\circ}$, symmetry code (iii) $x-1, y, z$ ) to form molecular sheets parallel to the bc-plane (figure S5).
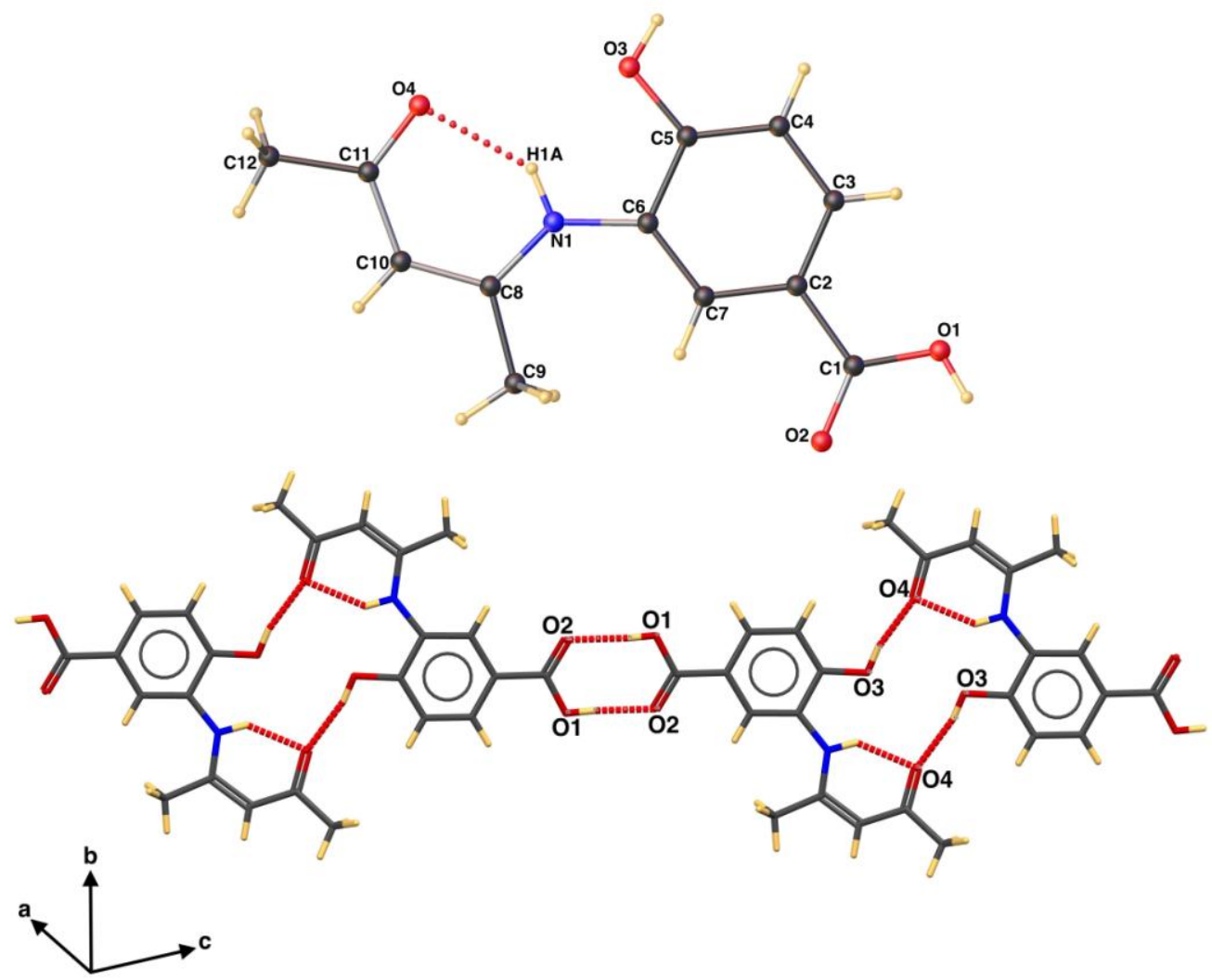

Figure 1. Top: Molecular view of the crystal structure of $\boldsymbol{H}_{3} \boldsymbol{L}^{\boldsymbol{I}}$.

Bottom: Partial view of the crystal structure of $\boldsymbol{H}_{3} \boldsymbol{L}^{1}$ showing the hydrogen bonds indicated by red dashed lines forming infinite chains (for details, see Table S2 and Figure S6 in the Supporting Information).

\subsubsection{Crystal and molecular structure of $H_{3} L^{2}(2)$}

X-Ray single crystal diffraction indicates that ligand $\boldsymbol{H}_{3} \boldsymbol{L}^{2}$ crystallizes with the presence of an equilibrium (Figure 3-b) ${ }^{[47]}$ between two zwitterionic species such as the iminium-carboxylate (molecule A) and the iminium-alcoholate (molecule B) (Figure 2) in a centrosymmetric monoclinic space group type $P 21 / n$ with two independents molecules in the asymmetric unit. Molecules $\mathbf{A}$ and $\mathbf{B}$ exist in zwitterion equilibrium between iminium cations, carboxylate $\left(\mathrm{O}_{2 \mathrm{~A}^{-}}\right.$ $\left.\mathrm{C}_{1 \mathrm{~A}}-\mathrm{O}_{1 \mathrm{~A}}\right)$ and phenolate anions $(\mathrm{O} 4 \mathrm{~B})$. Ligand $\boldsymbol{H}_{3} \boldsymbol{L}^{2}$ is planar, dihedral angles between aromatic ring through the $\mathrm{C}_{2}-\mathrm{C}_{7} / \mathrm{C}_{9}-\mathrm{C}_{14}$ moiety being 6.3(1) and $5.2(1)^{\circ}$ in molecules $\mathbf{A}$ and $\mathbf{B}$, respectively. The carboxylic groups in both molecules are coplanar with the mean planes of the attached aromatic rings. Intra- and intermolecular hydrogen bonds are observed in compound (2): strong intramolecular $\mathrm{N} 1-\mathrm{H} 1 \cdots \mathrm{O} 4$ are observed in each molecule between the hydrogen $\mathrm{H} 1$ of the $\mathrm{NH}$ group and the oxygen $\mathrm{O} 4$ of phenol group $\left(\mathrm{d}_{\mathrm{N} 1 \mathrm{~A}-\mathrm{O} 4 \mathrm{~A}}=2.604(3) \AA ; \angle \mathrm{N} 1 \mathrm{~A}-\mathrm{H} 1 \mathrm{~A}-\mathrm{O} 4 \mathrm{~A}=\right.$ $\left.135^{\circ} ; \mathrm{d}_{\mathrm{N} 1 \mathrm{~B}-\mathrm{O} 4 \mathrm{~B}}=2.54(3) \AA ; \angle \mathrm{N} 1 \mathrm{~A}-\mathrm{H} 1 \mathrm{~A}-\mathrm{O} 4=138^{\circ}\right)$. Several medium intermolecular $\mathrm{O}-\mathrm{H} \cdots \mathrm{O}$ 
hydrogen bonds interactions can be observed in $\boldsymbol{H}_{3} \boldsymbol{L}^{2}$ : the molecules $\mathrm{A}$ are connected via intermolecular $\mathrm{O}-\mathrm{H} \cdots \mathrm{O}$ hydrogen bonds between $\left[\mathrm{O}_{4 \mathrm{~A}}-\mathrm{H}_{4 \mathrm{~A}} \cdots \mathrm{O}_{2 \mathrm{~A}}\right.$; symmetry code: $\mathrm{x}+{ }^{1} t_{2},-\mathrm{y} \neq^{3} \mathrm{t}_{2}$, $\left.\mathrm{z}+{ }^{4} t_{2} \div \mathrm{d}_{\mathrm{O} 4 \mathrm{~A}-\mathrm{O} 2 \mathrm{~A}}=2.447(2) \AA<\mathrm{O}_{4 \mathrm{~A}}-\mathrm{H}_{4 \mathrm{~A}}-\mathrm{O}_{2 \mathrm{~A}}=165^{\circ}\right]$ to form a chains along the $\mathrm{c}$-axis and the angle between molecules $\mathbf{A}$ in the chain is $72.62(2)^{\circ}$. These chains are interconnected along the caxis to form a sheet through two $\mathrm{O}-\mathrm{H} \cdots \mathrm{O}$ intermolecular hydrogen bonds: $\left[\mathrm{O}_{2 \mathrm{~B}}-\mathrm{H}_{2 \mathrm{~B}} \cdots \mathrm{O}_{1 \mathrm{~A}}\right.$, symmetry code: $\left.\mathrm{x}+1, \mathrm{y}-1, \mathrm{z} ; \mathrm{d}_{\mathrm{O} 2 \mathrm{~B}-\mathrm{O} 1 \mathrm{~A}}=2.594(3) \AA ; \angle \mathrm{O}_{2 \mathrm{~B}}-\mathrm{H}_{2 \mathrm{~B}}-\mathrm{O}_{1 \mathrm{~A}}=145^{\circ}\right]$ and $\left[\mathrm{O}_{3 \mathrm{~A}}-\mathrm{H}_{3 \mathrm{~A}} \cdots \mathrm{O}_{4 \mathrm{~B}}\right.$ $; \mathrm{d}_{\mathrm{O} 3 \mathrm{~A}-\mathrm{O} 4 \mathrm{~B}}=2.598(3) \AA ; \quad \angle \mathrm{O}_{3 \mathrm{~A}}-\mathrm{H}_{3 \mathrm{~A}}-\mathrm{O}_{4 \mathrm{~B}}=169^{\circ}$ ]. These sheets are also interconnected along baxis by medium hydrogen bond type $\mathrm{O}-\mathrm{H} \cdots \mathrm{O}$ through $\left[\mathrm{O}_{3 \mathrm{~B}}-\mathrm{H}_{3 \mathrm{~B}} \cdots \mathrm{O}_{1 \mathrm{~A}}\right.$; symmetry code: $-\mathrm{x}+3 / 2$, $\left.\mathrm{y}-1 / 2, \mathrm{~d}_{\mathrm{O} 3 \mathrm{~B}-\mathrm{O} 1 \mathrm{~A}}=2.736(2) \AA ; \angle \mathrm{O}_{3 \mathrm{~B}}-\mathrm{H}_{3 \mathrm{~B}}-\mathrm{O}_{1 \mathrm{~A}}=177^{\circ}\right],\left[\mathrm{O}_{2 \mathrm{~B}}-\mathrm{H}_{2 \mathrm{~B}} \cdots \mathrm{O}_{1 \mathrm{~A}}\right]$ and $\left[\mathrm{O}_{3 \mathrm{~A}}-\mathrm{H}_{3 \mathrm{~A}} \cdots \mathrm{O}_{4 \mathrm{~B}}\right]$ (figure $\mathrm{S} 7$ ). In addition to these hydrogen bonding interactions, it is noteworthy that the cohesion in the crystal is ensured by weak interactions type $\pi \cdots \pi$ stacking, observed between centroid $(\mathrm{Cg} 1)$ of the $\mathrm{C} 2 \mathrm{~A}-\mathrm{C} 7 \mathrm{~A}$ phenyl ring and the centroid $(\mathrm{Cg} 2)$ of the $\mathrm{C} 9 \mathrm{~B}-\mathrm{C} 14 \mathrm{~B}$ phenyl ring, and between centroid $(\mathrm{Cg} 3)$ of the $\mathrm{C} 2 \mathrm{~B}-\mathrm{C} 7 \mathrm{~B}$ phenyl ring and the centroid $(\mathrm{Cg} 4)$ of the $\mathrm{C} 9 \mathrm{~A}-\mathrm{C} 14 \mathrm{~A}$ phenyl ring of the adjacent molecules, with $\mathrm{Cg} 1 \cdots \mathrm{Cg} 2$ distance of $3.894(3) \AA$ and $\mathrm{Cg} 3 \cdots \mathrm{Cg} 4$ distance of 3.579(3) $\AA$ respectively (Figure S6-right). The main geometrical features of $\boldsymbol{H}_{3} \boldsymbol{L}^{2}$ are given in Table S1. All H-bond interactions are summarized in table S2.

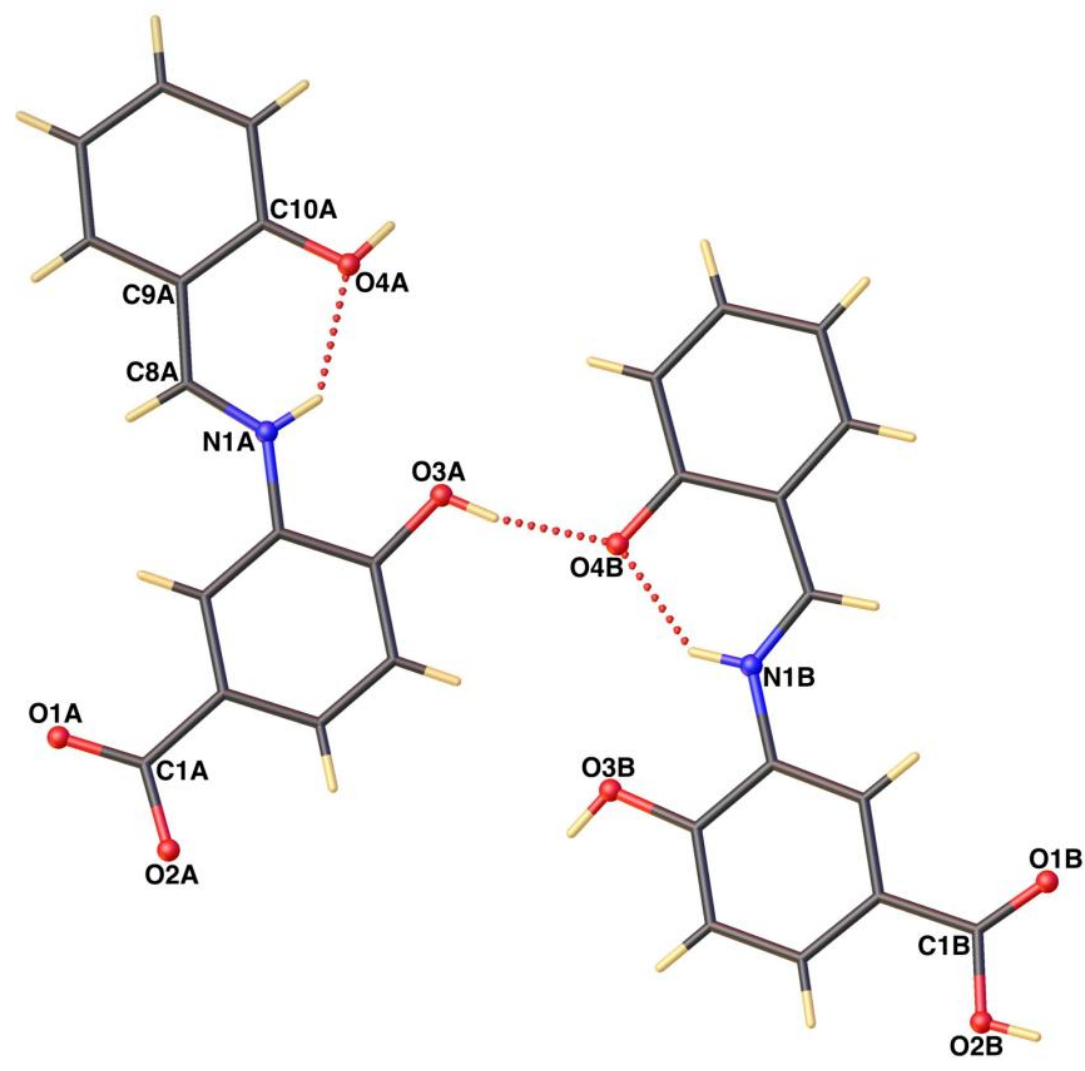




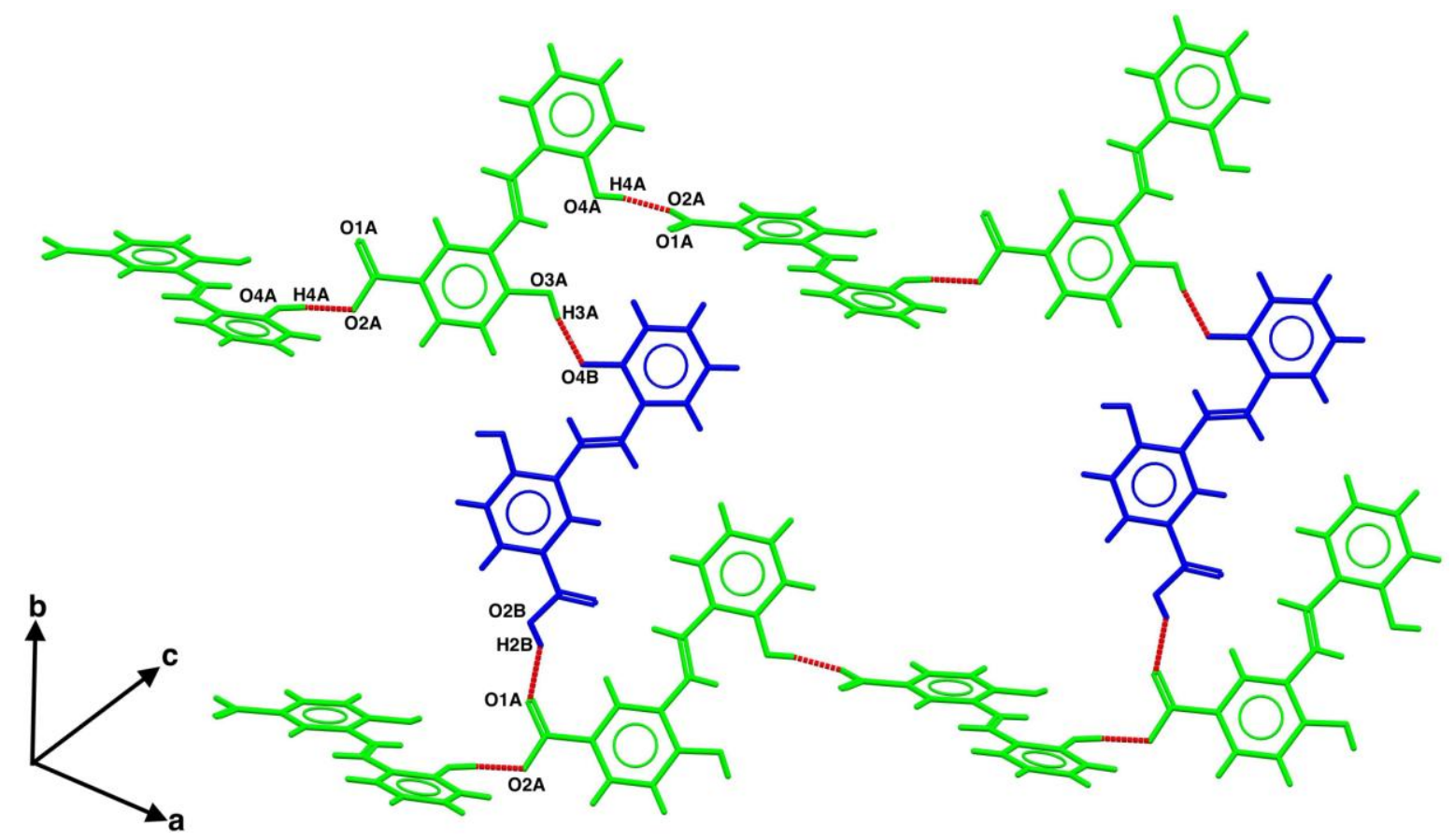

Figure 2. Top: Molecular view of the crystal structure of $\boldsymbol{H}_{3} \boldsymbol{L}^{2}$.

Bottom: Partial view of the crystal structure of $\boldsymbol{H}_{3} \boldsymbol{L}^{2}$ showing the hydrogen bonds indicated by red dashed lines, molecules $\mathbf{A}$ are represented in green and molecules $\mathbf{B}$ in blue (for details, see Table S2 and Figure S7 in the Supporting Information).

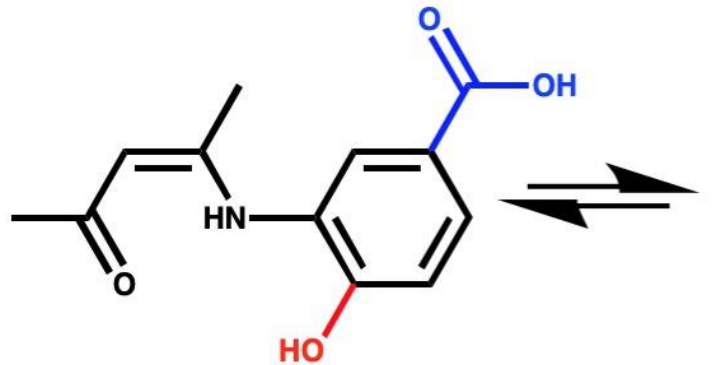

1A

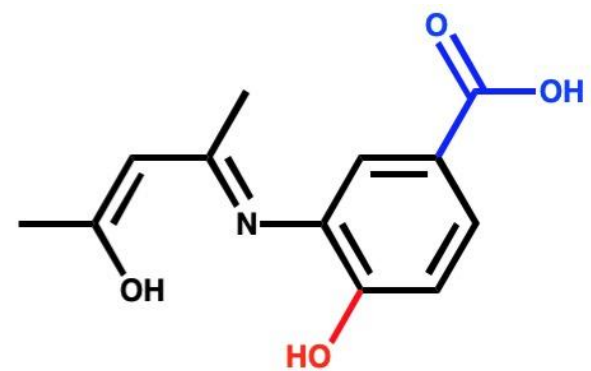

1B

(a)
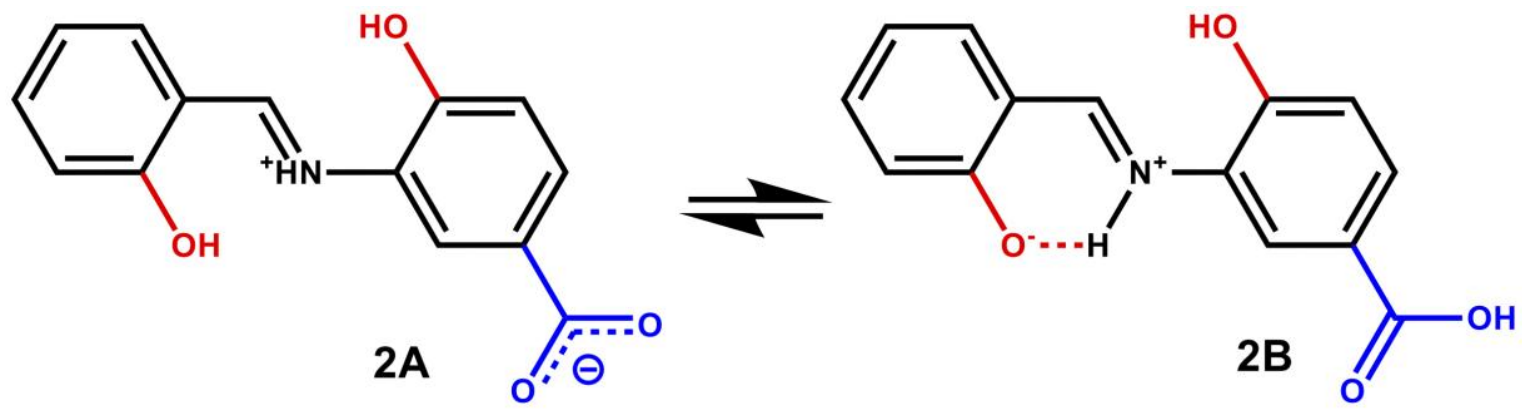

(b)

Figure 3. A) Tautomeric equilibrium: keto-enamine (1A) and enol-imine (1B) in $\boldsymbol{H}_{\mathbf{3}} \boldsymbol{L}^{1} \mathbf{B}$ ) Zwitterionic equilibrium (iminium- carboxylate (2A), iminium alcoholate (2B)) in $\boldsymbol{H}_{\mathbf{3}} \boldsymbol{L}^{\mathbf{2}}$. 


\subsubsection{Crystal and molecular structure of (C1)}

Compound $\boldsymbol{C} \boldsymbol{1}$ crystallizes in the monoclinic system with centrosymmetric space group $P 2 / C$ with a polymeric structure containing two independent copper ions (figure 4-top). The $\mathrm{Cu} 1$ centre is localized on an inversion centre and it is five-coordinated $\left[\mathrm{CuN}_{3} \mathrm{O}_{2}\right]$ with a distorted square-pyramidal coordination environment $(\tau=0.23$ where $\tau=$ difference between the two largest angles/60; $\tau=1$ for ideal trigonal-bipyramidal and $\tau=0$ for ideal square-pyramidal ${ }^{[48]}$ ). The coordination sphere of $\mathrm{Cu} 1$ is formed by three nitrogen atoms provided from three pyridine molecules $\left(\mathrm{N} 3, \mathrm{~N} 3^{\mathrm{ii}}, \mathrm{N} 4\right)$ and two oxygen atoms provided from two adjacent carboxylate groups of $\left(\boldsymbol{L}^{1}\right)^{3-}\left(\mathrm{O} 1,01^{\mathrm{ii}}\right)$. The second copper centre $(\mathrm{Cu} 2)$ is localized on a general position and it is five-coordinated $\left[\mathrm{CuN}_{2} \mathrm{O}_{3}\right]$ with a distorted square-pyramidal coordination environment $(\tau=0.21)$, the coordination sphere of $\mathrm{Cu} 2$ is formed by two nitrogen atoms $(\mathrm{N} 1, \mathrm{~N} 2)$ provided by the azomethine group and one pyridine, and three oxygen atoms $\left(\mathrm{O} 3, \mathrm{O}^{\mathrm{i}}, \mathrm{O} 4\right)$ provided by two phenoxido group $\left(\mathrm{O} 3, \mathrm{O}^{\mathrm{i}}\right)$ and carbonyl oxygen (O4). The diphenoxido bridging connects the $\mathrm{Cu} 2$ ion to the $\mathrm{Cu} 2^{\mathrm{i}}$ ion and forms a dimeric unit (Figure 4-top), the $\mathrm{Cu} 2 \cdots \mathrm{Cu} 2^{\mathrm{i}}$ distance through the phenoxido bridge is 3.246(3) $\AA$. The separation of $\mathrm{Cu} 1 \cdots \mathrm{Cu} 2$ through the whole amino-benzoic moiety is 8.593(4) $\AA$ and forms a polymeric chain. The $\mathrm{Cu}-\mathrm{O}$ and $\mathrm{Cu}-\mathrm{N}$ bond lengths are in the normal range and are close to those found in other reported $\mathrm{Cu}^{\mathrm{II}}$ complexes with similar Schiff bases ligands. ${ }^{[49]}$ The bridging $\mathrm{Cu} 2-\mathrm{O} 3-\mathrm{Cu} 2^{\mathrm{i}}$ angle is $97.451(3)^{\circ}$, the distances in the fragment: N1-C8-C9C10-O4 with values: $1.31 \AA, 1.41 \AA, 1.35 \AA$ and $1.28 \AA$ respectively, reveals that the delocalization of double bond in the $\mathrm{N}-\mathrm{C}-\mathrm{C}-\mathrm{C}-\mathrm{O}$ fragment of the ligand coordinated is in the keto form. In the crystal structure of $\boldsymbol{C 1}$, weak $\mathrm{C}-\mathrm{H} \cdots \mathrm{O}$ hydrogen-bonding interactions are observed between pyridine $\mathrm{C}-\mathrm{H}$ atoms and carboxylate oxygen atoms to form a threedimensional network (figure S7). In addition to these hydrogen bonds, one notices the presence of $\pi-\pi$ stacking interactions with an adjacent molecule, between centroid (cg1) of the N3-C18 pyridyl ring and the centroid (cg2) of the $\mathrm{N} 3^{\mathrm{i}}-\mathrm{C} 18^{\mathrm{i}}$ (i) $-\mathrm{x}, 1-\mathrm{y}-\mathrm{z}$ pyridyl ring of adjacent molecule (figure 4-bottom). 

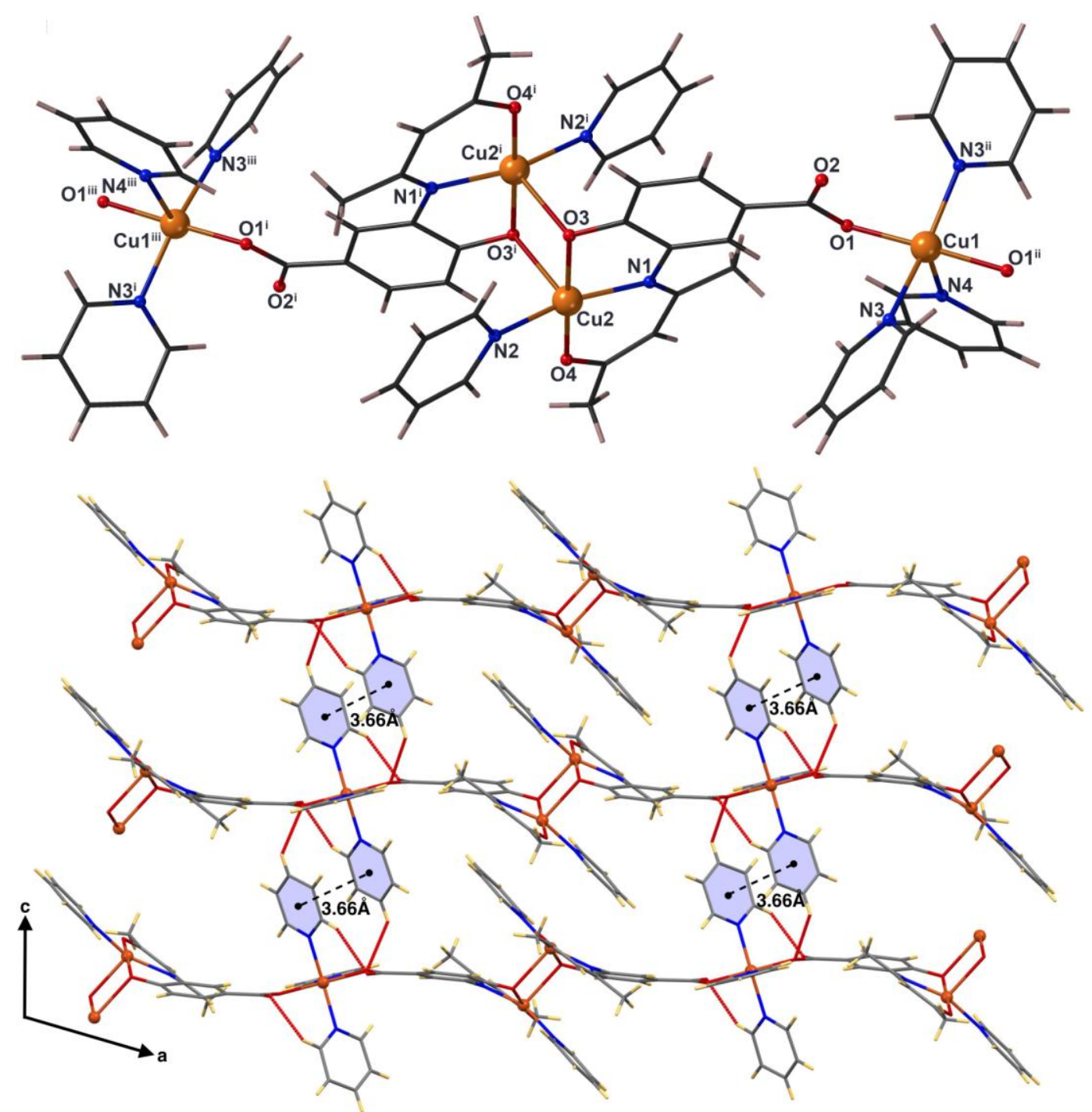

Figure 4. Top: ATOMS view of the crystal structure of $\left[\mathrm{Cu}_{2}\left(\mu-\boldsymbol{L}^{\boldsymbol{l}}\right)(\mathrm{Py})_{2}\right]_{\mathrm{n}} .(\boldsymbol{C 1})$. Bottom: Packing arrangement of $(\boldsymbol{C l})$ viewed along the (ac) plane. Symmetry operators for generating equivalent positions: ${ }^{(i)}=1-\mathrm{x}, 1-\mathrm{y}, 1-\mathrm{z} ;{ }^{(i i)}=-\mathrm{x}, \mathrm{y}, 1 / 2-\mathrm{z}$; ${ }^{(i i i)}=1+\mathrm{x}, 1-\mathrm{y}, 1 / 2+\mathrm{z}$

\subsubsection{Crystal and molecular structure of (C2)}

The compound $\boldsymbol{C} 2$ crystallizes in the monoclinic centro-symmetric space group $P 2 / n$ as a discrete structure. The molecular structure is depicted in Figure 5-top. The asymmetric unit displays one doubly deprotonated ligand $\left(\boldsymbol{H} \boldsymbol{L}^{2}\right)^{2-}$ (scheme 2) and one monodentate pyridine molecule. Compound $\boldsymbol{C 2}$ consists of a mononuclear $\mathrm{Ni}^{\mathrm{II}}$ complex involving an anionic ligand $\left(\boldsymbol{H L}^{2}\right)^{2-}$ and a pyridine molecule. The coordination of the nickel cation is pseudo-square planar with two oxygen atoms provided by the phenolate groups ( $\mathrm{O} 3$ and $\mathrm{O} 4)$ and two nitrogen atoms ( $\mathrm{N} 1$ and $\mathrm{N} 2$ ) originated from the ligand and the exogenous pyridine (Figure 6). Classical $(\mathrm{O}-\mathrm{H} \cdots \mathrm{O})$ and non-classical hydrogen bond $(\mathrm{C}-\mathrm{H} \cdots \mathrm{O})$ has been detected and form 2D sheets (Figure 5-bottom). 

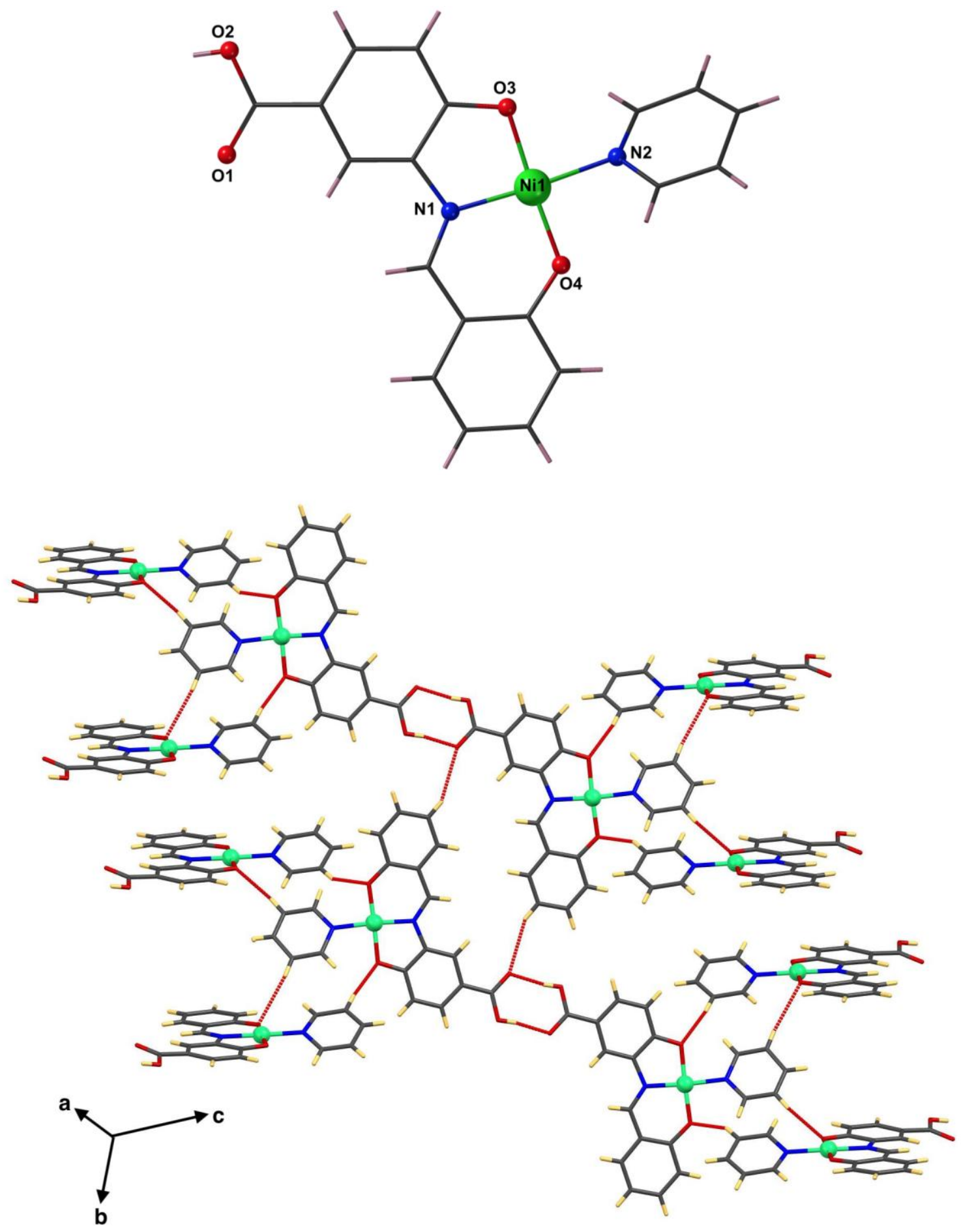

Figure 5. Top: ATOMS view of the crystal structure of $\left[\mathrm{Ni}\left(\boldsymbol{H} \boldsymbol{L}^{2}\right)(\mathrm{Py})\right](\boldsymbol{C 2})$.

Bottom: Partial view of the crystal structure of compound $(\boldsymbol{C} 2)$ showing the hydrogen bonds indicated by red dashed lines.

\subsubsection{Crystal and molecular structure of (C3)}

The molecular structure of $\boldsymbol{C} 3$ can be described as a coordination polymer $\left[\mathrm{Ni}^{\mathrm{II}}\left(\mathrm{H}^{2}\right)(\mathrm{Py})_{2}\right]_{n}$ as shown in Figure 6. It crystallizes in the orthorhombic system with centrosymmetric space group Pbca. Each $\mathrm{Ni}^{\mathrm{II}}$ cation is hexacoordinated forming elongated octahedrons. In the 
equatorial plane, the $\mathrm{Ni}^{\mathrm{II}}$ cations are surrounded by one doubly deprotonated chelating $\left(\mathrm{H} \boldsymbol{L}^{2}\right)^{2-}$ ligand (coordinated to the metal through oxygens O3, O4 of phenolate groups (scheme 2)) and nitrogen N1 for the azomethine group with the following distance: Ni1-O3 = 2.029(2) $\AA$, $\mathrm{Ni} 1-\mathrm{O} 4=2.014(2) \AA$ and $\mathrm{Ni} 1-\mathrm{N} 1=1.997(3) \AA$, the equatorial plane being completed by one oxygen $\mathrm{O} 1^{\mathrm{i}}$ provided by the monodentate carboxylate group of an adjacent molecule $(\mathrm{i}=$ $1 / 2+x, y, 1 / 2-y)$. Two exogenous pyridine molecules complete the octahedral site via two nitrogen atoms N2, N3 in apical positions with distances of Ni1-N2 $=2.154(3) \AA$, Ni1 $-\mathrm{N} 3$ $=2.135(3) \AA$, respectively. The Ni1 $\cdots \mathrm{Ni} 1^{\mathrm{i}}$ distance through the whole amino-benzoic moiety is $8.918 \AA$ and forms polymeric chains.

Moreover, two intermolecular hydrogen bonds can be identified in the crystal structures. The first $\mathrm{H}$-bond is observed in the chain between $\mathrm{OH}$ of carboxylate groups as donors and oxygen atoms of the first phenol groups as acceptors with $\mathrm{O} 2 \cdots \mathrm{O} 4$ distance of 2.508(4) $\AA$ with an angle $\mathrm{O} 2-\mathrm{H} 2-\mathrm{O} 4^{\mathrm{ii}}: 169^{\circ}(\mathrm{ii}=x-1 / 2, y,-z+1 / 2)$, the second is observed between $\mathrm{OH}$ of methanol crystallisation solvent and oxygen atoms of the second phenol

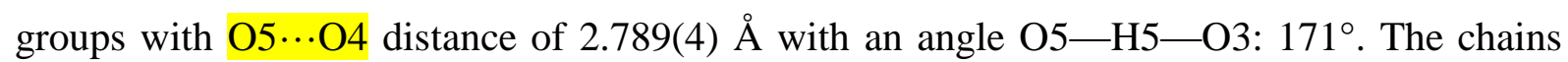
are connected through non-classical hydrogen bonds $\mathrm{CH} \cdots \mathrm{O}$ between $\mathrm{CH}$ groups of the pyridine rings and oxygen atoms of carboxylate groups to forms a 3D network (figure S8).

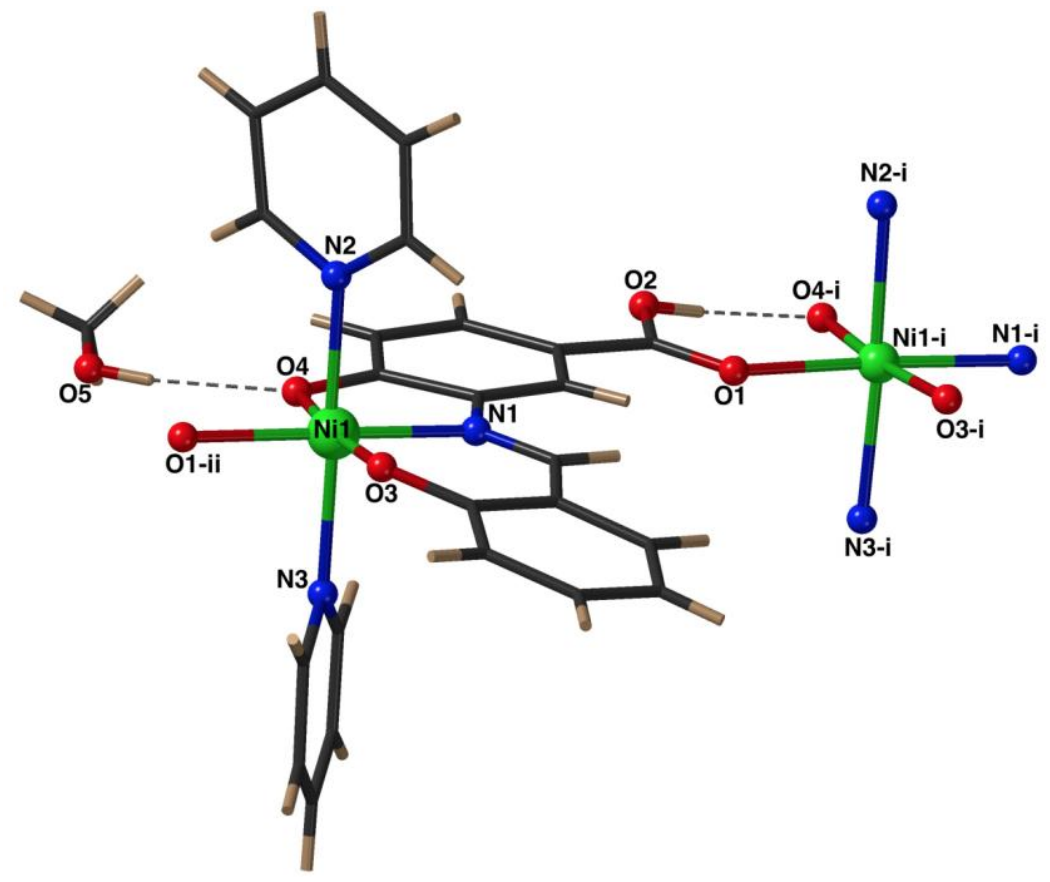




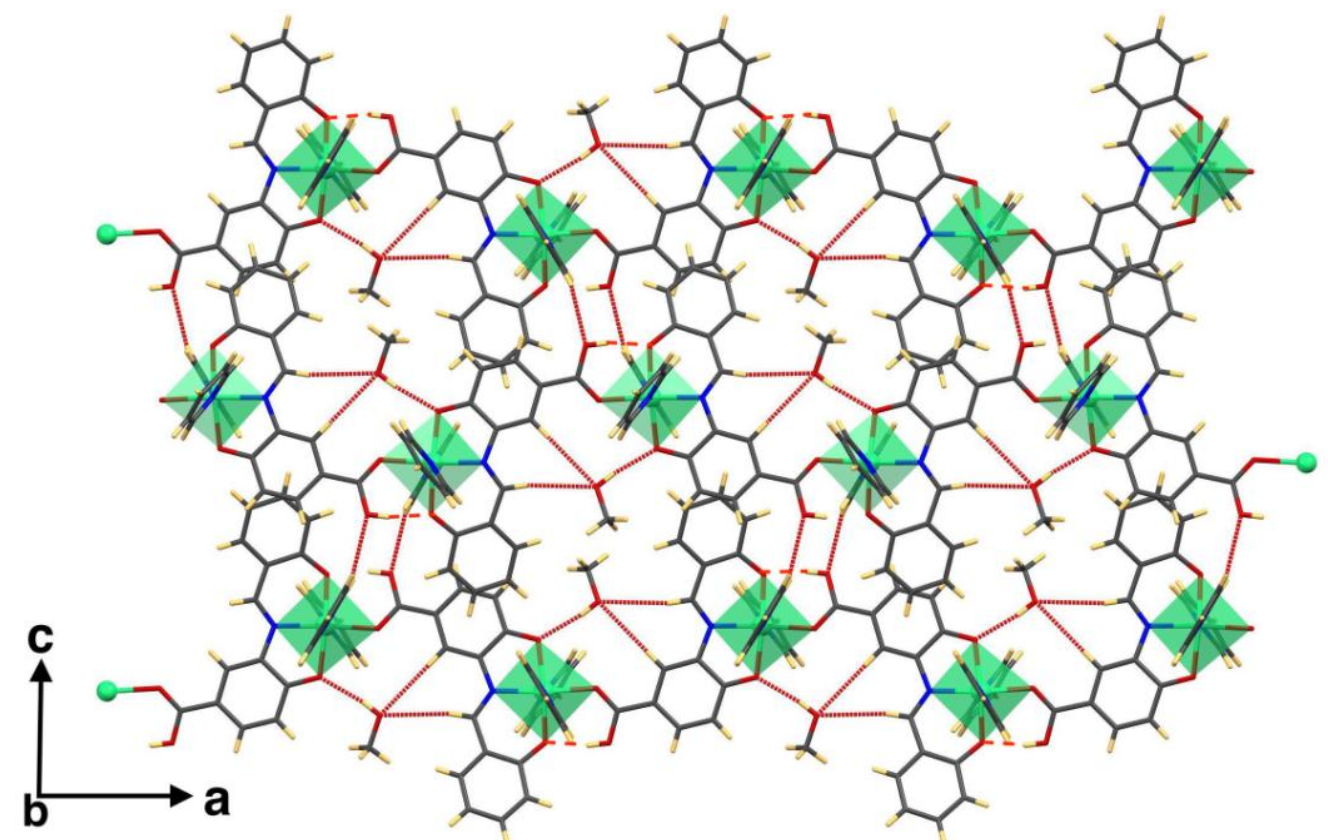

Figure 6. Top: ATOMS view of the crystal structure of $\left[\mathrm{Ni}\left(\boldsymbol{\mu}-\boldsymbol{H} \boldsymbol{L}^{2}\right)(\mathrm{Py})_{2}\right]_{\mathrm{n}}(\boldsymbol{C} 3)$. Bottom: Packing arrangement of $(\boldsymbol{C 3})$ viewed along the (ac) plane. Symmetry operators for generating equivalent positions: ${ }^{(i)}=-1 / 2+\mathrm{x}, \mathrm{y}, 1 / 2-\mathrm{z} ;{ }^{(i i)}=1 / 2+\mathrm{x}, \mathrm{y}, 1 / 2-\mathrm{Z}$<smiles></smiles>

$\mathrm{H}_{3} \mathrm{~L}^{1}$

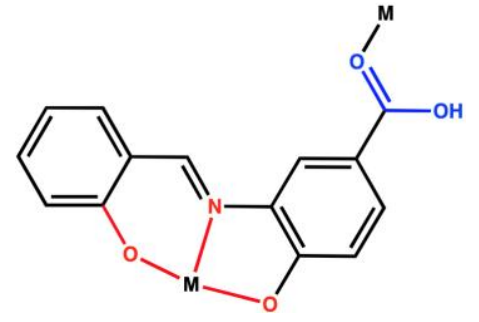

$\mathrm{H}_{3} \mathrm{~L}^{2}$

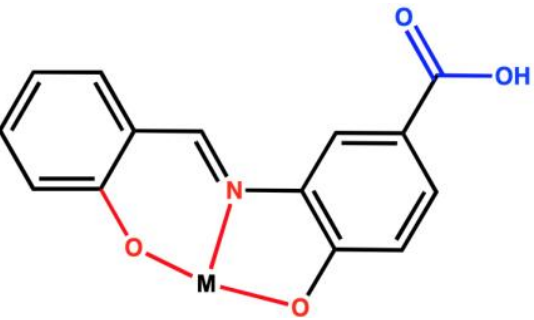

$\mathrm{H}_{3} \mathrm{~L}^{2}$

Scheme 2. Coordination modes for different forms of $\boldsymbol{H}_{3} \boldsymbol{L}^{1}$ and $\boldsymbol{H}_{3} \boldsymbol{L}^{2}$ (with $\mathrm{M}$ being the metal cation)

\subsection{Electronic spectra}

The UV-visible absorption spectra of the free ligands $\boldsymbol{H}_{3} \boldsymbol{L}^{1}$ and $\boldsymbol{H}_{3} \boldsymbol{L}^{2}$ and their complexes $\boldsymbol{C l}$ and $\mathbf{C 3}$ were recorded in EtOH and are shown in Figure 7. For $\boldsymbol{H}_{3} \boldsymbol{L}^{1}$, the absorption spectrum consists of two intense absorption bands centred at about 270 and $335 \mathrm{~nm}$. These absorptions can be ascribed to the lowest allowed $\pi \rightarrow \pi^{*}$ transitions of the benzenic system, which are derived from ${ }^{1} \mathrm{~B}_{2 \mathrm{u}} \rightarrow{ }^{1} \mathrm{~A}_{1 \mathrm{~g}}\left({ }^{1} L_{\mathrm{b}}\right.$ in Platt's notation) and ${ }^{1} \mathrm{~B}_{1 \mathrm{u}} \rightarrow{ }^{1} \mathrm{~A}_{1 \mathrm{~g}}\left({ }^{1} L_{\mathrm{a}}\right.$ in Platt's notation) transitions. The $\boldsymbol{H}_{3} \boldsymbol{L}^{2}$ ligand is characterized by the same set of absorption bands lying at about 270 and $345 \mathrm{~nm}$ which are related to the same $\pi \rightarrow \pi^{*}$ transitions. In addition to these $\pi \rightarrow \pi^{*}$ transitions, $\boldsymbol{H}_{3} \boldsymbol{L}^{2}$ ligand displays a much weaker visible and broad absorption band that can be ascribed to azomethine $\mathrm{n} \rightarrow \pi^{*}{ }^{[50]}$ It is noteworthy that this $\mathrm{n} \rightarrow \pi^{*}$ transition could not be seen for $\boldsymbol{H}_{3} \boldsymbol{L}^{1}$ likely due to the presence of the acac moiety. For the complexes, the two 
main absorption bands are significantly red-shifted due to metal binding. As a consequence, absorptions centred at about $290 \mathrm{~nm}$ and $285 \mathrm{~nm}$ can be seen for $\boldsymbol{C 1}$ and $\boldsymbol{C 3}$, respectively. Similarly, the low energy lying absorptions are also red-shifted of about 35-40 $\mathrm{nm}$ and constitute valuable metal binding probes. These features clearly indicated that phenolate units are involved in the metal binding. $\boldsymbol{C} \boldsymbol{1}$ stands in a very interesting contrast with $\boldsymbol{C} 3$ with the presence of a low and broad absorption tail.
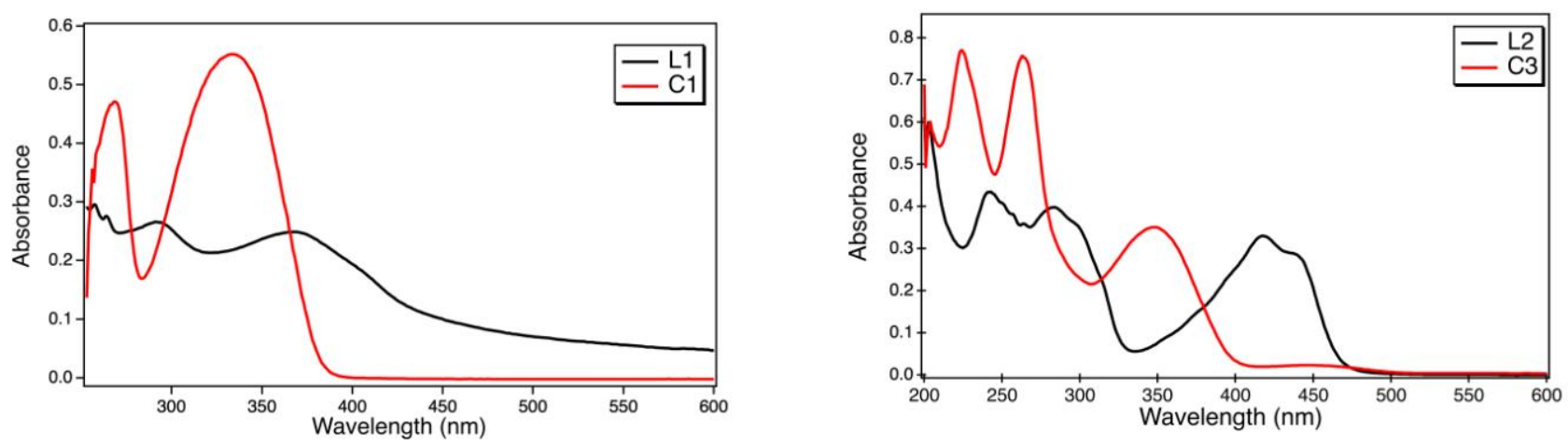

Figure 7. (left) $U V$-Vis absorption spectrum of compound $\boldsymbol{H}_{3} \boldsymbol{L}^{1}$ (black line) compared to that of its complex $\boldsymbol{C 1}$ (red line). (right) $U V$-Vis absorption spectrum of compound $\boldsymbol{H}_{3} \boldsymbol{L}^{2}$ (black line) compared to that of its complex $\boldsymbol{C} 3$ (red line). Solvent: $\mathrm{EtOH} ;\left[\boldsymbol{H}_{3} \boldsymbol{L}^{\mathbf{1}}\right]=8.02 \times 10^{-5} \mathrm{M} ;\left[\boldsymbol{H}_{3} \boldsymbol{L}^{2}\right]=9.26 \times 10^{-5} \mathbf{M} ;[\boldsymbol{C l}]=$ $2.77 \times 10^{-5} \mathrm{M} ;[\boldsymbol{C} 3]=4.88 \times 10^{-5} \mathrm{M}$.

\subsection{Antioxidant activities}

Synthetic antioxidants represent a large group of substances whose number continuously increases each year. ${ }^{[51]}$ In our study, we tested the two Schiff base ligands and their metallic complexes for their antioxidant properties using six different and complementary methods. The aim of this work was to establish the potential of these little-explored synthetic Schiff base derivatives as antiradical/antioxidant agents and to determine their mechanism of action. Antioxidants can indeed deactivate radicals by two major mechanisms: hydrogen atom transfer (HAT, capability of an antioxidant to quench free radicals by H-atom donation) and single electron transfer (SET, capacity of an antioxidant in the reduction of an oxidant/scavenging of radicals). ${ }^{[52]}$ Each method employed in this work allowed evaluating the global antioxidant capacities of the investigated compound that can result from different processes such as radical scavenging, redox properties, complexing of pro-oxidant metals, etc. ${ }^{[53]}$

The antioxidant activities of the free ligands and the corresponding metal complexes were assessed using six different and complementary assays, and the main results are depicted as 
$\mathrm{IC}_{50}$ or $\mathrm{A}_{0.5}$ values in Table 2. The first methods employing stable free radicals such as DPPH or $\mathrm{ABTS}^{*+}$ (bleaching assays) provided information on the radical scavenging capacities of the investigated systems (SET-based assays). As far as DPPH is concerned, $\boldsymbol{H}_{3} \boldsymbol{L}^{\boldsymbol{1}}$ and $\boldsymbol{H}_{3} \boldsymbol{L}^{\mathbf{2}}$ were found to be the more efficient radical scavengers in the reduction of this neutral organic radical than their corresponding complexes. $\boldsymbol{H}_{3} \boldsymbol{L}^{\boldsymbol{1}}$, characterized by an $\mathrm{IC}_{50}$ of $3.87 \pm 0.16$ $\mu \mathrm{g} / \mathrm{mL}$, displayed a scavenging activity against $\mathrm{DPPH}^{\bullet}$ greater than the standards examined in this work $\left(\right.$ BHA: $\mathrm{IC}_{50}=5.73 \pm 0.41 \mu \mathrm{g} / \mathrm{mL}$ or BHT: $\mathrm{IC}_{50}=22.32 \pm 1.19 \mu \mathrm{g} / \mathrm{mL}$ ). The same observation applies to $\boldsymbol{H}_{3} \boldsymbol{L}^{2}$, which showed an antiradical activity $\left(\mathrm{IC}_{50}: 22.25 \pm 0.32 \mu \mathrm{g} / \mathrm{mL}\right.$ ) similar to that of the standard BHT $(22.32 \pm 1.19 \mu \mathrm{g} / \mathrm{mL})$. The differences observed between $\boldsymbol{H}_{3} \boldsymbol{L}^{1}$ and $\boldsymbol{H}_{3} \boldsymbol{L}^{2}$ can be easily explained by the presence of an additional phenolic unit for $\boldsymbol{H}_{3} \boldsymbol{L}^{2}$. By contrast with the free ligands, the complexes weakly inhibited DPPH radical with $\mathrm{IC}_{50}$ values greater than $100 \mu \mathrm{g} / \mathrm{mL}$. This feature clearly indicates that upon metal complexation, the antiradical scavenging properties toward $\mathrm{DPPH}^{\circ}$ of the ligands are prevented. Therefore, the metal complexes $(\mathrm{Ni}$ or $\mathrm{Cu})$ are seemingly not capable to scavenge radicals.

With respect to the scavenging activities of $\mathrm{ABTS}^{\circ+}$ (cationic organic radical), all the investigated systems (free ligands or metal complexes) exhibited scavenging activities that were found to be comparable to those of the standards BHA or BHT. $\boldsymbol{H}_{3} \boldsymbol{L}^{\mathbf{1}}\left(\mathrm{IC}_{50}=3.51 \pm 0.07\right.$ $\mu \mathrm{g} / \mathrm{mL})$ was found to be the most potent and can be compared to $\boldsymbol{H}_{3} \boldsymbol{L}^{2}\left(\mathrm{IC}_{50}=4.03 \pm 0.16\right.$ $\mu \mathrm{g} / \mathrm{mL}$ ). As observed with DPPH', the complexes $\boldsymbol{C} 3$ and $\boldsymbol{C 1}$ were found to be significantly (p $\leq 0.0 .5$ ) less potent than the free ligands with $\mathrm{IC}_{50}$ values of $5.45 \pm 0.27$ and $4.59 \pm 0.05$ $\mu \mathrm{g} / \mathrm{mL}$, respectively. BHA and BHT displayed the highest inhibition activities and were significantly (p $\leq 0.05$ ) more potent than $\boldsymbol{H}_{3} \boldsymbol{L}^{1}$ and $\boldsymbol{H}_{3} \boldsymbol{L}^{2}$. The results obtained with ABTS ${ }^{\cdot+}$ are however in contradiction with those determined by the $\mathrm{DPPH}^{\bullet}$ method since sizeable scavenging properties were measured for the metal complexes.

To go further in the understanding of the mechanism of action, two other complementary methods that are also based on single electron transfer (SET) were used to probe the ability of a given scavenger to reduce metal complexes $(\mathrm{Cu}(\mathrm{II}) \rightarrow \mathrm{Cu}(\mathrm{I})$ for the CUPRAC method and $\mathrm{Fe}(\mathrm{III}) \rightarrow \mathrm{Fe}(\mathrm{II})$ for the Reducing Power method). Similarly to the results obtained with DPPH ${ }^{\bullet} \boldsymbol{H}_{3} \boldsymbol{L}^{1}$ and $\boldsymbol{H}_{3} \boldsymbol{L}^{2}$ were also found to be more potent than the standards BHA, BHT or ascorbic acid. $\boldsymbol{H}_{3} \boldsymbol{L}^{\boldsymbol{1}}$ reduces ferric ions with $\mathrm{A}_{0.5}$ value of $2.58 \pm 0.16 \mu \mathrm{g} / \mathrm{mL}$ and cupric ions with $\mathrm{A}_{0.5}$ of $2.74 \pm 0.42 \mu \mathrm{g} / \mathrm{mL}$. $\boldsymbol{H}_{3} \boldsymbol{L}^{\boldsymbol{1}}$ displays comparable $\mathrm{A}_{0.5}$ values of $3.33 \pm 0.12 \mu \mathrm{g} / \mathrm{mL}$ (Fe) and $3.75 \pm 0.18 \mu \mathrm{g} / \mathrm{mL}$ for $\mathrm{Fe}$ (III) and $\mathrm{Cu}$ (II) reduction, respectively. In both cases, the 
ability of the corresponding metal complexes $(\boldsymbol{C 1}$ and $\boldsymbol{C 3})$ to reduce ferric or copper ions has been markedly altered with much less efficient systems.

All together, these spectrophotometric SET-based methods $\left(\mathrm{DPPH}^{*}, \mathrm{ABTS}^{\circ+}, \mathrm{CUPRAC}^{-}\right.$ and Reducing Power) measure the capacity of an antioxidant in the reduction of an oxidant (DPPH ${ }^{\bullet}, \mathrm{ABTS}^{\bullet+}, \mathrm{Cu}(\mathrm{II})$ and $\mathrm{Fe}(\mathrm{III})$ ). The Schiff bases $\boldsymbol{H}_{3} \boldsymbol{L}^{1}$ and $\boldsymbol{H}_{3} \boldsymbol{L}^{2}$ are much more effective than their corresponding complexes thus suggesting the essential role of the free phenolic function to scavenge free radicals or to transfer electron to $\mathrm{Cu}$ (II) or $\mathrm{Fe}$ (III) metal ions. The involvement of these phenolic units in the coordination of metal ions $(\mathrm{Cu}$ and $\mathrm{Ni})$ seems to significantly reduce their ability to trap radicals.

We then turn our attention to the $\beta$-carotene-linoleic acid method that is based on the oxidation of linoleic acid triggered by $\mathrm{H}_{2} \mathrm{O}_{2}$. The generated radicals from linoleic acid oxidation then leads to bleaching of $\beta$-carotene. This HAT method measures the capacity of a given antioxidant to quench free radicals (generally peroxyl radicals) by H-atom donation. Very interestingly, $\boldsymbol{H}_{3} \boldsymbol{L}^{2}$ and its corresponding $\boldsymbol{C} \mathbf{3}$ complex display the most potent ability to protect $\beta$-carotene from bleaching by the generated radicals from linoleic acid oxidation with $\mathrm{IC}_{50}$ values of $0.47 \pm 0.04 \mu \mathrm{g} / \mathrm{mL}$ and $0.41 \pm 0.06 \mu \mathrm{g} / \mathrm{mL}$, respectively. $\boldsymbol{H}_{3} \boldsymbol{L}^{2}$ and $\boldsymbol{C} 3$ were found to be more efficient than BHA and BHT standards $\left(\mathrm{IC}_{50}: 0.90 \pm 0.02 \mu \mathrm{g} / \mathrm{mL}\right.$ and $1.05 \pm$ $0.01 \mu \mathrm{g} / \mathrm{mL}$, respectively). Due to the presence of only one phenolic group, $\boldsymbol{H}_{3} \boldsymbol{L}^{1}$ was found to be less potent $\left(\mathrm{IC}_{50}=1.52 \pm 0.11 \mu \mathrm{g} / \mathrm{mL}\right)$ while complex $\boldsymbol{C 1}$ was inactive. These data strongly indicate that $\boldsymbol{H}_{3} \boldsymbol{L}^{2}$ and its $\mathrm{Ni}(\mathrm{II})$ complex $(\boldsymbol{C} 3)$ can trap radicals either by SET or HAT mechanism.

We finally investigated the capacity of our systems to firmly bind $\mathrm{Fe}(\mathrm{II})$ by competing with $\mathrm{Fe}(\mathrm{II})$-ferene species (complexation of pro-oxidant metal ions, Ferrous Chelating assay).[45] While $\boldsymbol{H}_{3} \boldsymbol{L}^{1}$ has been shown to be inactive, $\boldsymbol{H}_{3} \boldsymbol{L}^{2}$ with an extra-phenolic group competes slightly $\left(\mathrm{IC}_{50}: 153.97 \pm 6.64 \mu \mathrm{g} / \mathrm{mL}\right.$ ) with $\mathrm{Fe}(\mathrm{II})$-ferene, far below the $\mathrm{IC}_{50}$ value measured for EDTA used as a standard $\left(\mathrm{IC}_{50}: 12.11 \pm 0.32 \mu \mathrm{g} / \mathrm{mL}\right)$. The most striking result concerns complex $\boldsymbol{C} 3$ that exhibited the highest chelating activity of ferrous(II) giving an $\mathrm{IC}_{50}$ value of $14.43 \pm 0.26 \mu \mathrm{g} / \mathrm{ml}(\mathrm{p} \leq 0.05)$ close to that of the standard EDTA. The capacity of these Schiff bases to afford dinuclear complexes as seen for $\boldsymbol{C l}$ complex (inactive in this assay) could rationalize the capacity of complex $\boldsymbol{C} 3$ to compete with $\mathrm{Fe}(\mathrm{II})$-ferene.

Among the examined systems, $\boldsymbol{H}_{3} \boldsymbol{L}^{2}$ and complex $\boldsymbol{C} 3$ were found to be the most potent antioxidants displaying both valuable SET, HAT and Fe(II) metal binding capacities. This 
work thus contributes to broaden the knowledge of this family of compounds whose antioxidant properties have so far been little considered.

Table 2. Antioxidant activity of ligands and their complexes.

\begin{tabular}{|c|c|c|c|c|c|c|}
\hline Compound & $\begin{array}{l}\text { DPPH IC }_{50} \\
(\mu \mathrm{g} / \mathrm{ml})\end{array}$ & $\begin{array}{l}\text { ABTS IC }_{50} \\
(\mu \mathrm{g} / \mathrm{ml})\end{array}$ & $\begin{array}{l}\beta \text {-Carotene } \\
\mathrm{IC}_{50}(\mu \mathrm{g} / \mathrm{ml})\end{array}$ & $\begin{array}{l}\text { Iron chelating } \\
\mathrm{IC}_{50}(\mu \mathrm{g} / \mathrm{ml})\end{array}$ & $\begin{array}{l}\text { CUPRAC } \\
A_{0,5}(\mu \mathrm{g} / \mathrm{ml})\end{array}$ & $\begin{array}{l}\text { Reducing power } \\
\mathbf{A}_{0,5}(\mu \mathrm{g} / \mathrm{ml})\end{array}$ \\
\hline $\mathrm{H}_{3} \mathrm{~L}^{I}$ & $22.25 \pm 0.32^{\mathrm{c}}$ & $3.51 \pm 0.07^{\mathrm{c}}$ & $1.52 \pm 0.11^{\mathrm{d}}$ & NA & $2.58 \pm 0.16^{\mathrm{a}}$ & $2.74 \pm 0.42^{\mathrm{a}}$ \\
\hline$H_{3} L^{2}$ & $3.87 \pm 0.16^{\mathrm{a}}$ & $4.03 \pm 0.16^{\mathrm{d}}$ & $0.47 \pm 0.04^{\mathrm{a}}$ & $153.97 \pm 6.64^{\mathrm{c}}$ & $3.33 \pm 0.12^{\mathrm{b}}$ & $3.75 \pm 0.18^{b}$ \\
\hline$C 1$ & $>100$ & $4.59 \pm 0.05^{\mathrm{e}}$ & NA & $145.16 \pm 5.17^{\mathrm{c}}$ & $13.93 \pm 0.78^{\mathrm{e}}$ & $18.59 \pm 1.25^{\mathrm{e}}$ \\
\hline$C 3$ & $>100$ & $5.45 \pm 0.27^{\mathrm{f}}$ & $0.41 \pm 0.06^{\mathrm{a}}$ & $14.43 \pm 0.26^{\mathrm{b}}$ & $6.61 \pm 0.37^{\mathrm{c}}$ & $13.57 \pm 1.26^{\mathrm{d}}$ \\
\hline BHA & $5.73 \pm 0.41^{b}$ & $1.81 \pm 0.10^{\mathrm{b}}$ & $0.90 \pm 0.02^{\mathrm{b}}$ & NT & $3.64 \pm 0.19^{b}$ & $8.41 \pm 0.67^{\mathrm{c}}$ \\
\hline BHT & $22.32 \pm 1.19^{c}$ & $1.29 \pm 0.30^{\mathrm{a}}$ & $1.05 \pm 0.01^{\mathrm{c}}$ & NT & $9.62 \pm 0.87^{\mathrm{d}}$ & $>50$ \\
\hline Ascorbic acid & NT & NT & NT & NT & NT & $9.01 \pm 1.46^{\mathrm{c}}$ \\
\hline EDTA & NT & NT & NT & $12.11 \pm 0.32^{\mathrm{a}}$ & NT & NT \\
\hline
\end{tabular}

Results were expressed as means \pm SD of three parallel measurements $(n=3)$ and Analysis of Variance (ANOVA) was performed (Tukey test, $p \leq 0.05$ ). Results with different superscript letters are significantly different $(\mathrm{a}<\mathrm{b}<\mathrm{c}<\mathrm{d}<\mathrm{e}<\mathrm{f})$. NT: Not tested, NA: No Activity.

\subsection{Magnetic properties}

The magnetic properties of $\boldsymbol{C l}$ were measured on a polycrystalline sample under an applied dc field of 5000 Oe. The fit of the $1 / \chi=\mathrm{f}(T)$ curve using the Curie-Weiss law provides a Curie constant $\mathrm{C}=1.45 \mathrm{emu} \cdot \mathrm{K} \cdot \mathrm{mol}^{-1}$, slightly higher than the expected value for three noninteracting $\mathrm{Cu}(\mathrm{II})$ ions $\left(1.36 \mathrm{emu} \cdot \mathrm{K} \cdot \mathrm{mol}^{-1}\right.$ considering $\left.g=2.2\right)$ and a positive $\theta$ value $(\theta=4$ $\mathrm{K})$, indicating dominant ferromagnetic interactions. Upon cooling, the $\chi T$ product increases up to a maximum at $18 \mathrm{~K}\left(1.67 \mathrm{emu} \cdot \mathrm{K} \cdot \mathrm{mol}^{-1}\right)$. Below this maximum, the $\chi T$ product decreases down to $1.44 \mathrm{emu} \cdot \mathrm{K} \cdot \mathrm{mol}^{-1}$ at $1.8 \mathrm{~K}$. This behaviour can be fitted considering a $1 \mathrm{D}$ magnetic system with alternating magnetic interactions $J_{1}$ between $\mathrm{Cu} 1$ and $\mathrm{Cu} 2$ and $J_{2}$ between the two neighboring $\mathrm{Cu} 2$ ions. Such a chain topology cannot be treated exactly; therefore, we considered a ring of 9 spins to reproduce the chain behaviour without edge effect. The numerical resolution of the Hamiltonian was carried out by using the program PHI. ${ }^{[54]}$ The fit was performed simultaneously $\chi(T), \chi T(T)$ and $\mathrm{M}(H)$ at $1.8 \mathrm{~K}$, considering the following Hamiltonian for spin-spin interactions:

$$
\mathbf{H}=\Sigma-J_{i j} \mathbf{S}_{\mathrm{i}} \mathbf{S}_{\mathbf{j}}
$$


To avoid over-parameterization, and given the approximations made (finite size of the model, absence of interchain interactions), we considered an equal $\mathrm{g}$ factor for all spin centres. The fit leads to the following refined values: $g=2.29(1), J_{1}=-0.22(1) \mathrm{cm}^{-1}$ and $J_{2}=11.2(1) \mathrm{cm}^{-1}$ (Figures 8 and 9). As expected, the $\mathrm{Cu} 1-\mathrm{Cu} 2$ interaction (via the whole amino-benzoic moiety) is very small, whereas the $\mathrm{Cu} 2-\mathrm{Cu} 2$ interaction (via the phenoxy bridge $\mathrm{O} 3$ ) is much larger. The ferromagnetic character of the $J_{1}$ interaction is totally in line with the $\mathrm{Cu} 2 \mathrm{OCu} 2$ angle $\left(97.6^{\circ}\right)$ (Figure 5). ${ }^{[55]}$

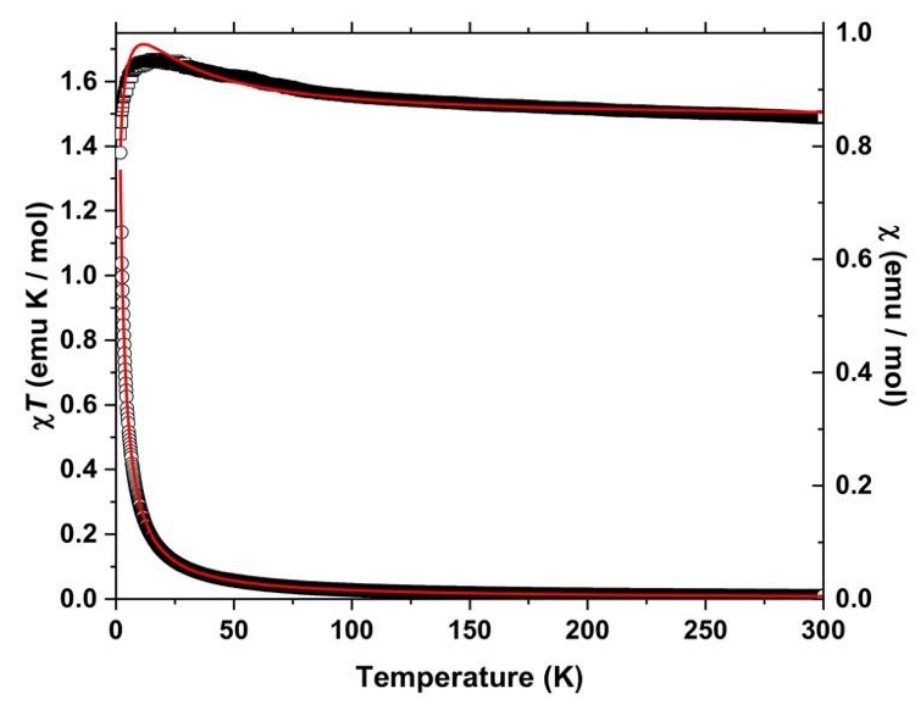

Figure 8. $\chi$ (open circles) and $\chi T$ (open squares) for $\boldsymbol{C} \boldsymbol{1}$ measured under a 5000 Oe dc field. Full red lines correspond to the best fit of the data (see text).

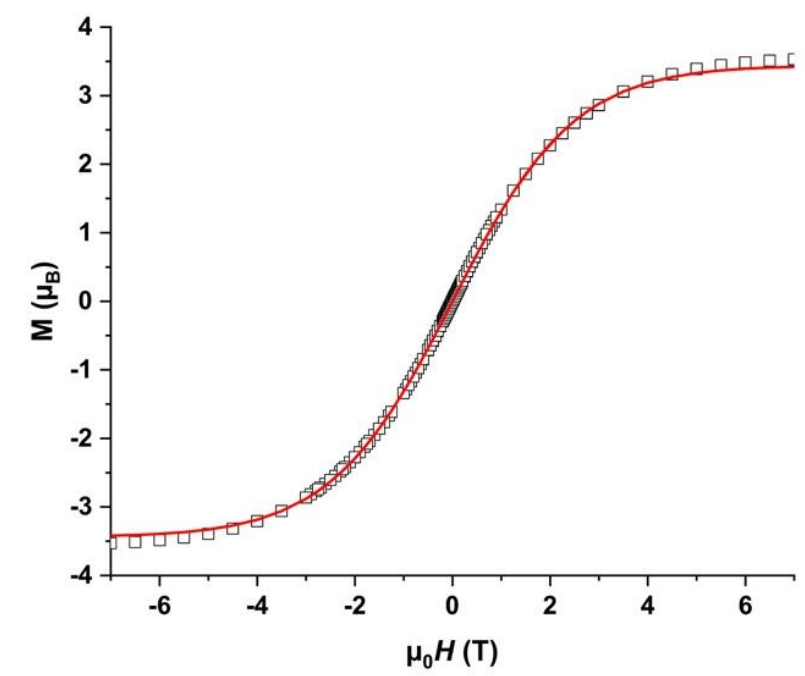

Figure 9. $\mathrm{M}=\mathrm{f}(H)$ at $1.8 \mathrm{~K}$ for $\boldsymbol{C 1}$ (open squares: experimental points, full red line: best fit of the data (see text)). 


\section{Conclusion}

In the present work, two novel tridentate Schiff-base carboxylate ligands $\left(\boldsymbol{H}_{3} \boldsymbol{L}^{\boldsymbol{1}}\right.$ and $\boldsymbol{H}_{3} \boldsymbol{L}^{2}$ ) and their copper(II) and nickel(II) complexes have been synthesized and fully characterized. Reaction of $\boldsymbol{H}_{3} \boldsymbol{L}^{1}$ with copper(II) acetate led to the formation of a 1D coordination polymer, while reaction of $\boldsymbol{H}_{3} \boldsymbol{L}^{2}$ with nickel(II) acetate in DMF afforded a monomer, and gave 1D coordination polymer in methanol. Copper(II) ions adopt a distorted square-pyramidal coordination geometry in $\boldsymbol{C 1}$, while nickel ions adopt a pseudo-square plane geometry in $\boldsymbol{C 2}$ and elongated octahedral coordination geometry in $\boldsymbol{C 3}$. The triply deprotonated $\left(\boldsymbol{L}^{\boldsymbol{1}}\right)^{-3}$ coordinates in a keto form and acts as tetradentate for complex $\boldsymbol{C l}$ through an ONO donor system provided by the Schiff base backbone and $\mathrm{O}$ donor from auxiliary carboxylate group. The doubly deprotonated $\left(\boldsymbol{H} \boldsymbol{L}^{2}\right)^{-2}$ coordinates in an enol-imine form and acts as tridentate for complex $\boldsymbol{C 2}$ through an ONO donor system. For complex $\boldsymbol{C 3}$, tetracoordination is provided by the ONO donor system and the $\mathrm{O}$ from carboxylate group. The two Schiff base ligands and their complexes were examined for their antioxidant activities. Importantly, $\boldsymbol{H}_{3} \boldsymbol{L}^{2}$ and complex $\boldsymbol{C} 3$ were found to be the most potent antioxidants scavenging radicals by both SET and HAT mechanisms and displaying Fe(II) metal binding capacities. These Schiff bases that compete with BHA, BHT or EDTA thus constitute valuable derivatives that could find applications as antioxidants or antimicrobial agents. Lastly, the magnetic behaviour of complex $\boldsymbol{C l}$ is that of quasi-isolated chains with alternate FAF magnetic interactions.

\section{Conflicts of interest}

There are no conflicts to declare.

\section{Acknowledgements}

This is part of the Ph.D. thesis work of Ahlem Boussadia. We thank University Frères Mentouri Constantine 1, MESRS (Algeria), University of Strasbourg and CNRS (France) for financial support. The authors also acknowledge the support from the Labex NIE (ANR-11LABX-0058_NIE within the Investissement d'Avenir program ANR-10-IDEX-0002-02). 


\section{References:}

[1] A. Kanaani, D. Ajloo, G. Grivani, A. Ghavami, M. Vakili, Journal of Molecular Structure, 1112 (2016) 87-96.

[2] A. Kundu, N.A. Shakil, D.B. Saxena, Pankaj, J. Kumar, S. Walia, Journal of Environmental Science and Health, Part B, 44 (2009) 428-434.

[3] W. Qin, S. Long, M. Panunzio, S. Biondi, Molecules, 18 (2013) 12264-12289.

[4] H. Ünver, M. Yıldız, B. Dülger, Ö. Özgen, E. Kendi, T.N. Durlu, Journal of Molecular Structure, 737 (2005) 159-164.

[5] A. Kajal, S. Bala, S. Kamboj, N. Sharma, V. Saini, Journal of Catalysts, 2013 (2013) 1-14.

[6] E. Hadjoudis, I.M. Mavridis, Chemical Society Reviews, 33 (2004) 579-588.

[7] A.M. Abu-Dief, I.M.A. Mohamed, Beni-Suef University Journal of Basic and Applied Sciences, 4 (2015) 119-133.

[8] H. Achira, Y. Hoga, I. Yoshikawa, T. Mutai, K. Matsumura, H. Houjou, Polyhedron, 113 (2016) 123-131.

[9] A.E. Vaughn, D.B. Bassil, C.L. Barnes, S.A. Tucker, P.B. Duval, Journal of the American Chemical Society, 128 (2006) 10656-10657.

[10] H. Keypour, A. Shooshtari, M. Rezaeivala, F.O. Kup, H.A. Rudbari, Polyhedron, 97 (2015) 75 82.

[11] K.S.O. Ferraz, N.F. Silva, J.G. da Silva, L.F. de Miranda, C.F.D. Romeiro, E.M. SouzaFagundes, I.C. Mendes, H. Beraldo, European Journal of Medicinal Chemistry, 53 (2012) 98-106.

[12] H. Yu, Y. Tan, D. Kuang, F. Zhang, W. Jiang, Inorganica Chimica Acta, 496 (2019) 119044.

[13] D. Laziz, C. Beghidja, N. Baali, B. Zouchoune, A. Beghidja, Inorganica Chimica Acta, 497 (2019) 119085.

[14] D.-Y. Wu, O. Sato, Y. Einaga, C.-Y. Duan, Angewandte Chemie International Edition, 48 (2009) 1475-1478.

[15] R. Ruamps, L.J. Batchelor, R. Maurice, N. Gogoi, P. Jiménez-Lozano, N. Guihéry, C. de Graaf, A.-L. Barra, J.-P. Sutter , T. Mallah, Chemistry - A European Journal, 19 (2013) 950-956.

[16] D. Mondal, M.C. Majee, K. Bhattacharya, J. Long, J. Larionova, M.M. Khusniyarov, M. Chaudhury, ACS Omega, 4 (2019) 10558-10570.

[17] E. Colacio, J.M. Domínguez-Vera, M. Ghazi, R. Kivekäs, M. Klinga, J.M. Moreno, European Journal of Inorganic Chemistry, 1999 (1999) 441-445.

[18] S. Eyele-Mezui, E. Delahaye, G. Rogez, P. Rabu, European Journal of Inorganic Chemistry, 2012 (2012) 5225-5238.

[19] K.C. Gupta, A.K. Sutar, Coordination Chemistry Reviews, 252 (2008) 1420-1450.

[20] R. Drozdzak, B. Allaert, N. Ledoux, I. Dragutan, V. Dragutan, F. Verpoort, Coordination Chemistry Reviews, 249 (2005) 3055-3074.

[21] B. Sarkar, S. Konar, C.J. Gómez-García, A. Ghosh, Inorganic Chemistry, 47 (2008) 11611 11619.

[22] F.C. Frederick, W.M. Coleman, L.T. Taylor, Inorganic Chemistry, 22 (1983) 792-795.

[23] Y. Zhang, R. Lv, J. Wang, L. Yang, S. Liao, J. Tian, W. Gu, X. Liu, Dalton Transactions, 45 (2016) 3247-3250.

[24] V. Tangoulis, G. Psomas, C. Dendrinou-Samara, C.P. Raptopoulou, A. Terzis, D.P. Kessissoglou, Inorganic Chemistry, 35 (1996) 7655-7660.

[25] S.J. Rettig, R.C. Thompson, J. Trotter, S. Xia, Inorganic Chemistry, 38 (1999) 1360-1363.

[26] J.-M. Rueff, C. Paulsen, J. Souletie, M. Drillon, P. Rabu, Solid State Sciences, 7 (2005) 431-436.

[27] J.-M. Rueff, N. Masciocchi, P. Rabu, A. Sironi, A. Skoulios, Chemistry - A European Journal, 8 (2002) 1813-1820.

[28] A. Beghidja, G. Rogez, P. Rabu, R. Welter, M. Drillon, Journal of Materials Chemistry, 16 (2006) 2715-2728.

[29] A. Beghidja, P. Rabu, G. Rogez, R. Welter, Chemistry - A European Journal, 12 (2006) 76277638.

[30] A. Beghidja, S. Hallynck, R. Welter, P. Rabu, European Journal of Inorganic Chemistry, 2005 (2005) 662-669. 
[31] L.K. Thompson, S.K. Mandal, S.S. Tandon, J.N. Bridson, M.K. Park, Inorganic Chemistry, 35 (1996) 3117-3125.

[32] K. Rakesh, H. Manukumar, D.C. Gowda, Bioorganic \& medicinal chemistry letters, 25 (2015) 1072-1077.

[33] W. Al Zoubi, A.A.S. Al - Hamdani, M. Kaseem, Applied Organometallic Chemistry, 30 (2016) 810-817.

[34] Bruker APEX2 and SAINT, Bruker AXS Inc., Madison, Wisconsin, USA., (2007).

[35] G.M. Sheldrick, Acta Cryst., C71 (2015) 3.

[36] C.F. Macrae, P.R. Edgington, P. McCabe, E. Pidcock, G.P. Shields, R. Taylor, M. Towler, J. van de Streek, J. Appl. Cryst., 39 (2006) 453-457.

[37] D.C. Palmer, CrystalMaker. CrystalMaker Software Ltd, Begbroke, Oxfordshire, England., (2014).

[38] A. L. Spek, Acta Cryst., D65 (2009) 148-155.

[39] M.S. Blois, Nature, 181 (1958) 1199.

[40] R. Re, N. Pellegrini, A. Proteggente, A. Pannala, M. Yang, C. Rice-Evans, Free Radical Biology and Medicine, 26 (1999) 1231-1237.

[41] G.J. Marco, Journal of the American Oil Chemists' Society, 45 (1968) 594-598.

[42] M. Oyaizu, Jpn. J. Nutr., 44 (1986) 307-315.

[43] R. Apak, K. Güçlü, M. Özyürek, S.E. Çelik, Microchimica Acta, 160 (2008) 413-419.

[44] R. Apak, K. Güçlü, M. Özyürek, S.E. Karademir, Journal of Agricultural and Food Chemistry, 52 (2004) 7970-7981.

[45] D.J. Hennessy, G.R. Reid, F.E. Smith, S.L. Thompson, Canadian Journal of Chemistry, 62 (1984) 721-724.

[46] F.H. Allen, O. Kennard, D.G. Watson, L. Brammer, A.G. Orpen, R. Taylor, Typical distances: organic compound in international Tables for crystallography, (1992).

[47] E. Temel, C. Alaşalvar, H. Eserci, E. Ağar, Journal of Molecular Structure, 1128 (2017) 5-12.

[48] A.W. Addison, T.N. Rao, J. Reedijk, J. van Rijn, G.C. Verschoor, Journal of the Chemical Society, Dalton Transactions, (1984) 1349-1356.

[49] H. Hosseini-Monfared, R. Bikas, R. Szymczak, P. Aleshkevych, A.M. Owczarzak, M. Kubicki, Polyhedron, 63 (2013) 74-82.

[50] P.P. Netalkar, A. Kamath, S.P. Netalkar, V.K. Revankar, Spectrochimica Acta Part A: Molecular and Biomolecular Spectroscopy, 97 (2012) 762-770.

[51] D.M. Radomska-Leśniewska, P. Skopiński, B.J. Bałan, A. Białoszewska, J. Jóźwiak, D. Rokicki, E. Skopińska-Różewska, A. Borecka, A. Hevelke, Cent Eur J Immunol, 40 (2015) 249-262.

[52] H. Moharram, M. Youssef, Alexandria Journal of Food Science and Technology, 11 (2014) 3142.

[53] İ. Gülçin, Ö.İ. Küfrevioğlu, M. Oktay, M.E. Büyükokuroğlu, Journal of Ethnopharmacology, 90 (2004) 205-215.

[54] N.F. Chilton, R.P. Anderson, L.D. Turner, A. Soncini, K.S. Murray, Journal of Computational Chemistry, 34 (2013) 1164-1175.

[55] V.H. Crawford, H.W. Richardson, J.R. Wasson, D.J. Hodgson, W.E. Hatfield, Inorganic Chemistry, 15 (1976) 2107-2110. 